\title{
Benthic foraminifera or Ostracoda? Comparing the accuracy of palaeoenvironmental indicators from a Pleistocene lagoon of the Romagna coastal plain (Italy)
}

\author{
Giulia Barbieri and Stefano Claudio Vaiani \\ Dipartimento di Scienze Biologiche, Geologiche e Ambientali, University of Bologna, \\ via Zamboni 67 Bologna, 40127, Italy \\ Correspondence: Giulia Barbieri (giulia.barbieri21@unibo.it)
}

Received: 30 October 2017 - Revised: 29 December 2017 - Accepted: 6 January 2018 - Published: 29 January 2018

\begin{abstract}
Integrated analyses of multiple groups of microfossils are frequently performed to unravel the palaeoenvironmental evolution of subsurface coastal successions, where the complex interaction among several palaeoecological factors can be detected with benthic assemblages. This work investigates the palaeoenvironmental resolution potential provided by benthic foraminifera and ostracoda within a Pleistocene lagoonal succession of the Romagna coastal plain (northern Italy). Quantitative approaches and statistical techniques have been applied to both groups in order to understand the main factors that controlled the composition of assemblages and compare the palaeoecological record provided by single fossil groups.

The two faunal groups are characterized by the high dominance of opportunistic species (Ammonia tepidaAmmonia parkinsoniana and Cyprideis torosa); however, detailed palaeoecological information is inferred from less common taxa. Benthic foraminiferal assemblages are mainly determined by the frequencies of abnormal individuals and species related to high concentrations of organic matter, showing two assemblages: a stressed assemblage, consistent with a brackish-water environment subject to salinity and oxygen fluctuations, and an unstressed assemblage, which indicates more stable conditions. Despite the lower number of species, ostracoda show more significant differences in terms of species composition and ecological structure between their three assemblages, formed in response to a salinity gradient and indicative of inner, central, and outer lagoon conditions. The stratigraphic distribution of ostracod assemblages shows a general transgressive-regressive trend with minor fluctuations, whereas benthic foraminifera highlight the presence of a significant palaeoenvironmental stress.

In this case, the higher abundance along the stratigraphic succession, the higher differentiation of the assemblages, and the well-defined relationship between taxa and ecological parameters determine Ostracoda as the most reliable fossil group for precise palaeoenvironmental reconstructions. Nevertheless, benthic foraminifera indicate palaeoenvironmental stress and can be used to refine the environmental interpretation in the presence of monospecific ostracod assemblages.
\end{abstract}

\section{Introduction}

The use of microfossils as palaeoenvironmental proxies is quite common in geological studies since they are sensitive to a great number of ecological factors. Benthic foraminifera and Ostracoda are widely applied for stratigraphic and palaeoecological purposes since both of them have (i) an extremely wide distribution, from continental water bodies to the deep ocean; (ii) a short reproductive cycle that allows them to react quickly to environmental changes; and (iii) a hard shell that guarantees a high preservation potential in sediments (Murray, 2006; Rodriguez-Lazaro and RuizMuñoz, 2012). These characteristics also make them suitable for ecological studies in modern environments, especially in the paralic realm, where benthic foraminifera and ostracoda are particularly abundant. Special attention has been reserved 
for lagoons because today their fragile equilibrium is endangered by a series of factors, such as anthropogenic pollution and climatic changes. Composition and structure of assemblages have been described in relation to many ecological parameters, allowing the use of recent assemblages as "modern analogues" of fossil associations.

Benthic foraminiferal assemblages are determined by multiple factors, which sometimes create stressed conditions. Benthic foraminifera have been proved to be excellent environmental bio-indicators in paralic environments, such as estuaries and lagoons (Coccioni, 2000; Frontalini et al., 2009; Armynot du Châtelet and Debenay, 2010). Under stressed conditions, these microorganisms modify the community structure and develop a series of peculiar morphological abnormalities of the test (Alve, 1991). Abundant studies have been focused on the response of benthic foraminifera to anthropogenic pollution (Yanko et al., 1994; Alve, 1995; Armynot du Châtelet and Debenay, 2010; Frontalini and Coccioni, 2011), but foraminiferal abnormalities can also occur from natural stresses, such as extreme values of salinity, nutrients, oxygen, or very rapid changes in ecological parameters (Scott and Medioli, 1980; Almogi-Labin et al., 1992; Geslin et al., 2002). High concentrations of aberrant benthic foraminifera also occur in fossil assemblages, even though only a few cases are reported in the literature and are attributed to low or oscillating salinity (Bik, 1964; Bugrova, 1975; Wang et al., 1985). As suggested by Boltovskoy et al. (1991), the presence of highly deformed assemblages in both modern and fossil environments is not related to a single factor, but it may be produced by a series of ecological parameters. Although assessing which is the main ecological factor that led to the creation of deformities is generally difficult, the relative abundance of aberrant benthic foraminifera is a good proxy for palaeoenvironmental stress (Geslin et al., 2002).

Nevertheless, benthic foraminifera could be absent in environments characterized by strong fluctuations in salinity, organic matter, and hydrodynamic conditions (Laut et al., 2016; Pint and Frenzel, 2017). Conversely, ostracoda are abundant from freshwater to hyperhaline environments and guarantee a great continuity of palaeoecological information (Rodriguez-Lazaro and Ruiz-Muñoz, 2012). Even if paralic environments with unstable environmental parameters are often characterized by oligotypic assemblages dominated by opportunistic taxa, rare species provide reliable information (Slack et al., 2000). Salinity is considered one of the major controlling factors affecting the distribution of ostracoda; therefore, this group is often applied for palaeosalinity reconstructions (Gliozzi and Mazzini, 1998; Marco-Barba et al., 2013; Amorosi et al., 2014). However, a combination of factors usually affects benthic assemblages in transitional environments, determining the degree of confinement, defined as the time of renewal for marine waters (Guélorget and Perthuisot, 1983). Ostracod assemblages can be indicative of a wide range of parameters, including the salinity and the degree of isolation from the sea, as it has been recently demonstrated by Salel et al. (2016) in the Gulf of Lion and Ebro Delta (western Mediterranean).

Both benthic foraminifera and ostracoda can provide a wide range of palaeoenvironmental information (type of substrate, salinity, organic matter content, oxygen concentration, etc.), but each group has peculiar characteristics that make it more suitable as a proxy for specific conditions. Within back-barrier sediment successions, the interaction of sediment supply, accommodation space, and eustatic oscillations produces subtle environmental changes detectable by the combined application of benthic foraminifera and ostracoda. However, palaeoenvironmental reconstructions performed on both groups are rarely applied and mostly based on qualitative or semi-quantitative approaches (e.g. Rossi et al., 2011; Trog et al., 2013), whereas quantitative analyses and statistical methods are often applied to only a single fossil group (e.g. Marco-Barba et al., 2013; Vaiani and Pennisi, 2014). Integrated analyses of multiple fossil groups are scarcely available in the literature and they are mostly restricted to the postglacial period (e.g. Cearreta et al., 2003; Amorosi et al., 2014).

The aim of this work is to compare the palaeoenvironmental resolution potential of Foraminifera and Ostracoda through multivariate analysis of fossil assemblages within a Pleistocene short sedimentary succession of the Po River coastal plain. Composition and structure of assemblages have been analysed in detail in order to investigate the ability of each group to highlight specific palaeoecological conditions within the same stratigraphic interval.

\section{Geological setting}

The Po River coastal plain is the easternmost part of the Po Plain (Fig. 1), a foredeep system bounded by the Alps to the north and the northern Apennines to the south, filled with Pliocene-Quaternary sediments with a maximum thickness of $7 \mathrm{~km}$ in the major depocenters (Pieri and Groppi, 1981; Castellarin and Vai, 1986). Geophysical investigations have evidenced that the Po basin is deformed by diffuse north-verging thrusts, but the late Quaternary sediments were deposited under relatively undisturbed conditions (Regione Emilia-Romagna and ENI-AGIP, 1998).

Detailed subsurface studies on the Po coastal plain revealed a cyclic facies architecture of transgressive-regressive (T-R) cycles formed by alternated alluvial and wedge-shaped coastal deposits (Amorosi and Colalongo, 2005). Integrated pollen analyses and radiocarbon dates performed on the three uppermost T-R cycles allowed their attribution from Marine Isotope Stage (MIS) 7 to 1 (Amorosi et al., 1999a, 2004). Specifically, thick alluvial sediments including scarce pollen of non-arboreal taxa are related to cold conditions, whereas abundant deciduous and broadleaved pollens are included within back-barrier and shallow marine deposits formed dur- 


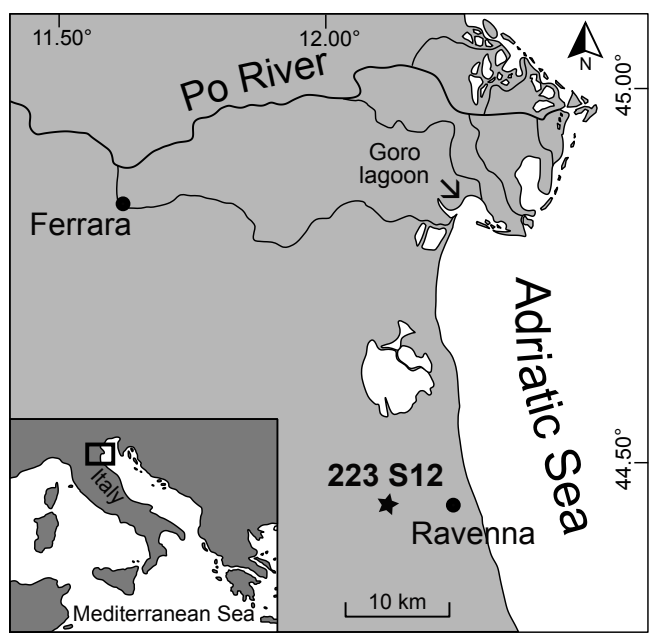

Figure 1. Location map of core $223 \mathrm{~S} 12$.

ing interglacial periods (MIS 1, 5, and 7; Amorosi et al., 1999a, 2004). This suggests that T-R cycles were formed in response to glacio-eustatic fluctuations with a frequency of $100 \mathrm{kyr}$, determined by the Milankovitch eccentricity-driven cycles (Lisiecki and Raymo, 2005).

The two most recent coastal wedges show a retrogradational stacking pattern of coastal plain and littoral facies, interpreted as a landward-migrating barrier-lagoon-estuary system during the transgressive phase, followed by deltaic and coastal progradation related to high stand conditions (Amorosi et al., 2004).

Lagoonal sediments in the subsurface of the Po River coastal plain are commonly developed within back-barrier facies associations. These are generally thin (1-2 m) at the base of Holocene (MIS 1) and Eemian (MIS 5e) transgressive-regressive wedges and are truncated at the top by an erosive ravinement surface that marks the passage to transgressive barrier facies (e.g. Amorosi et al., 2004; Campo et al., 2017). In contrast, well-developed paralic successions are locally present close to the innermost palaeoshoreline position reached at the peak of the MIS 1 and 5e transgressions (Dinelli et al., 2013; Campo et al., 2017) or below the Eemian units, representing the sedimentary response to the MIS 7 sea level variation (Amorosi et al., 1999a; Vaiani and Pennisi, 2014). Specifically, below the two uppermost T-R cycles, coastal and paralic deposits attributed to MIS 7 were recognized at some locations of the Po River coastal plain at more than $140 \mathrm{~m}$ core depth (e.g. Fiorini and Vaiani, 2001; Bondesan et al., 2006). The age attribution is supported by the stratigraphic position and the comparison with Mediterranean pollen zones, which limit the deposition of this interval during the late Middle Pleistocene (Amorosi et al., 1999a).

\section{Materials and methods}

The analysed succession is part of core $223 \mathrm{~S} 12$, drilled approximately $14 \mathrm{~km}$ inland from the modern shoreline near the city of Ravenna (Fig. 1) by wireline perforation, which guaranteed a continuous and undisturbed core stratigraphy, with recovery percentages higher than $90 \%$. This core reached a depth of $170 \mathrm{~m}$ and includes two paralic to shallow marine intervals formed in response to MIS 1 and 5.5 interglacials and a lagoonal interval attributed to MIS 7; these are alternated by continental deposits formed during glacial periods (Amorosi et al., 1999b, 2004). The detailed distribution of benthic foraminifera in the upper $130 \mathrm{~m}$ of this succession, including the MIS 1 and 5.5 interglacials, is reported in Fiorini (2004); this work is focused on the lower portion of this core, between ca. 165 and $160 \mathrm{~m}$ core depth, dated to the MIS 7 (Amorosi et al., 1999b), which has not been studied in detail.

Micropalaeontological analyses were performed on 19 sediment samples of ca. $150 \mathrm{~g}$ that were treated with a standard method as reported, for instance, in Amorosi et al. (1999b) and in Fiorni and Vaiani (2001): (i) dried for $8 \mathrm{~h}$ at $60^{\circ} \mathrm{C}$, (ii) soaked in water, (iii) wet-sieved at $63 \mu \mathrm{m}$ (240 mesh), and (iv) dried again. The obtained residue was examined under a binocular microscope to qualitatively analyse the meiofauna. Foraminiferal tests were subsequently separated with flotation from 16 samples with abundant fauna, using carbon tetrachloride $\left(\mathrm{CCl}_{4}\right)$. Both the light (floated) and the heavy fractions were dry-sieved through a $125 \mu \mathrm{m}$ sieve to concentrate adult tests and avoid problems of specific attribution on juvenile moults and individuals. The obtained light residue was then split into small proportions containing at least 300 specimens of benthic foraminifera, which were counted and identified. For all samples, the light fraction was then added to the heavy residue, including most of ostracoda, and split into portions including at least 300 ostracod valves for quantitative analyses. At the same time, benthic foraminifera were counted within the same residue to determine the relative proportion of the two groups. The micropalaeontological samples are housed in the Department of Biological, Geological and Environmental Sciences of the University of Bologna.

Identification of taxa was supported by original descriptions (Ellis and Messina, 1940). Furthermore, several reference works focusing on detailed taxonomy of Elphidiidae (Hansen and Lykke-Andersen, 1976; Hayward et al., 1997) and on the Mediterranean benthic foraminifera (e.g. Jorissen, 1988; Cimerman and Langer, 1991; Fiorini and Vaiani, 2001; Milker and Schmiedl, 2012) have been used for specific attribution of benthic foraminifera. Additional taxonomical remarks are reported in Appendix A. Due to the remarkable presence of deformed benthic foraminifera, the foraminiferal abnormality index (FAI, defined as the percentage of aberrant specimens in each sample) was calculated (Frontalini and Coccioni, 2008). Morphological abnormali- 
ties of tests were identified following Yanko et al. (1994), Geslin et al. (1998), and Coccioni (2000). Ostracod identification is also supported by works of Bonaduce et al. (1975), Breman (1975), Athersuch et al. (1989), Henderson (1990), and Mazzini et al. (1999). Photographs of specimens were obtained using a scanning electron microscope JEOL JSM 5200 at the Department of Biological, Geological and Environmental Sciences of the University of Bologna. A detailed analysis of the most common benthic foraminifera has been carried out due to their high morphological variability, and selected images are depicted in Plates 1 and 2.

Data matrices for multivariate statistical analyses were produced considering the most abundant taxa, with a frequency $>1 \%$ in at least one sample for both groups, in order to reduce background noise produced by rare species. Analyses performed on the full data matrix and with cut-off levels of 3 and $4 \%$ show that the composition of clusters is stable; therefore, a $1 \%$ cut-off level was applied, as suggested by other studies on benthic foraminifera and ostracoda of transitional environments (e.g. Frontalini et al., 2013; MartínezGarcia et al., 2013). The benthic foraminiferal data matrix included the 14 most common taxa or groups and the relative abundance of deformed specimens (FAI) as an additional variable. A total of 10 species or morphotypes were included in the ostracod data matrix. Specifically, Cyprideis torosa was differentiated in noded and un-noded forms because these two morphotypes are related to different environmental conditions, as evidenced by several works (e.g. Keyser and Aladin, 2004; Frenzel et al., 2012; Pint et al., 2012). Prior to statistical analyses, a logarithmic transformation $\left(\log _{10}(X+1)\right.$, where $X$ is the number of tests or valves) was applied to relative abundance data in order to increase the contribution of less abundant species and to reduce the overwhelming effect of the dominant taxa. One sample including only 277 ostracod valves ( $163.65 \mathrm{~m}$ core depth) was included in the data matrix since it can be considered a significant number for quantitative analysis on ostracod assemblages (Boomer et al., 2003) and it enhances the accuracy of the palaeoenvironmental reconstruction.

A Q-mode cluster analysis, using an unweighted pair group method with arithmetic mean algorithm (UPGMA), was performed in order to group samples with similar fauna. To further evaluate the null hypothesis of no variability in the faunal composition between benthic assemblages, a oneway analysis of similarities (ANOSIM; Clarke, 1993) with 9999 permutations was carried out. This test compares the ranks of distances within groups with ranks of distances between groups: if the dissimilarity between groups is greater than that within groups, $p$ values are $<0.5$ and groups are considered to be distinct. A similarity percentage (SIMPER) analysis defined the main taxa responsible for the differences between groups. These analyses were based on the BrayCurtis dissimilarity, a measure that does not take into account the absence of species, but it focuses on the composition of assemblage and the relative abundances of taxa (Field et al., 1982; Legendre and Legendre, 2012).

To characterize the biodiversity of assemblages, four faunal parameters were calculated: (1) species diversity $(S)$, the number of species in each sample; (2) dominance $(D)$; (3) Shannon-Weaver index $(H)$, a measure of entropy that considers the distribution of taxa among the total individuals (Shannon, 1948); and (4) Pielou's evenness $(J)$, to describe how individuals are divided between taxa (Pielou, 1975). Finally, differences between the structure of assemblages were tested using a Euclidean-based ANOSIM on $D, H$, and $J$. In this case, the Euclidean distance was chosen because it retains the mean and variance properties of original data, including the 0 values.

Multivariate statistical analyses and calculation of diversity indices were carried out using the software PAST (PAlaeontological STatistic - version 3.10 by Hammer et al., 2001) as specifically designed for palaeontological analyses.

\section{Results}

All 16 samples included abundant ostracod valves and were counted for quantitative analysis. Due to the low abundance of benthic foraminifera at the base (163.95-163.50 m core depth) and at the top (160.85-160.55 m core depth) of the studied interval, only 11 samples were quantitatively analysed to determine the benthic foraminiferal fauna.

\subsection{Benthic foraminifera diversity and assemblages}

A total of 4756 benthic foraminifera, belonging to 36 taxa, have been counted and identified between 163.50 and $160.95 \mathrm{~m}$ core depth (Table S1 in the Supplement). The high morphological variability shown by Elphidiidae and $\mathrm{Am}$ monia specimens allowed the identification of several taxa, which are described in detail in the taxonomic section (Appendix A) and depicted in Plates 1 and 2.

Species richness $(S)$ varies from 12 (sample at $161.45 \mathrm{~m}$ depth) to $23(163.05 \mathrm{~m})$ (Table 1). Dominance $(D)$ shows a maximum value of 0.33 in the sample at $161.45 \mathrm{~m}$, whereas the minimum corresponds to 0.12 at $163.20 \mathrm{~m}$ core depth. The lowest value of Shannon-Weaver index $(H)$ is recorded at $161.45 \mathrm{~m}$ core depth (1.42) and the highest is reached at $163.20 \mathrm{~m}$ core depth (2.29). Pielou's evenness $(J)$ varies from 0.57 (161.25 and $161.45 \mathrm{~m}$ core depth) to 0.79 (163.20 m core depth).

Ammonia parkinsoniana and intermediate A. tepida-A. parkinsoniana forms generally dominate the foraminiferal fauna (20.54 and $33.03 \%$ on average, respectively), with subordinate Haynesina germanica (13.89\%), Aubignyna perlucida (7.99\%), Ammonia tepida (7.16\%), and Cribroelphidium granosum $(5.35 \%)$. Lower concentrations of Haynesina depressula (2.66\%), Elphidium sp. 1 (1.86\%), Cribroelphidium oceanense (1.60\%), Elphidium advenum $(1.40 \%)$, and Elphidium clavatum $(1.31 \%)$ are recorded. 

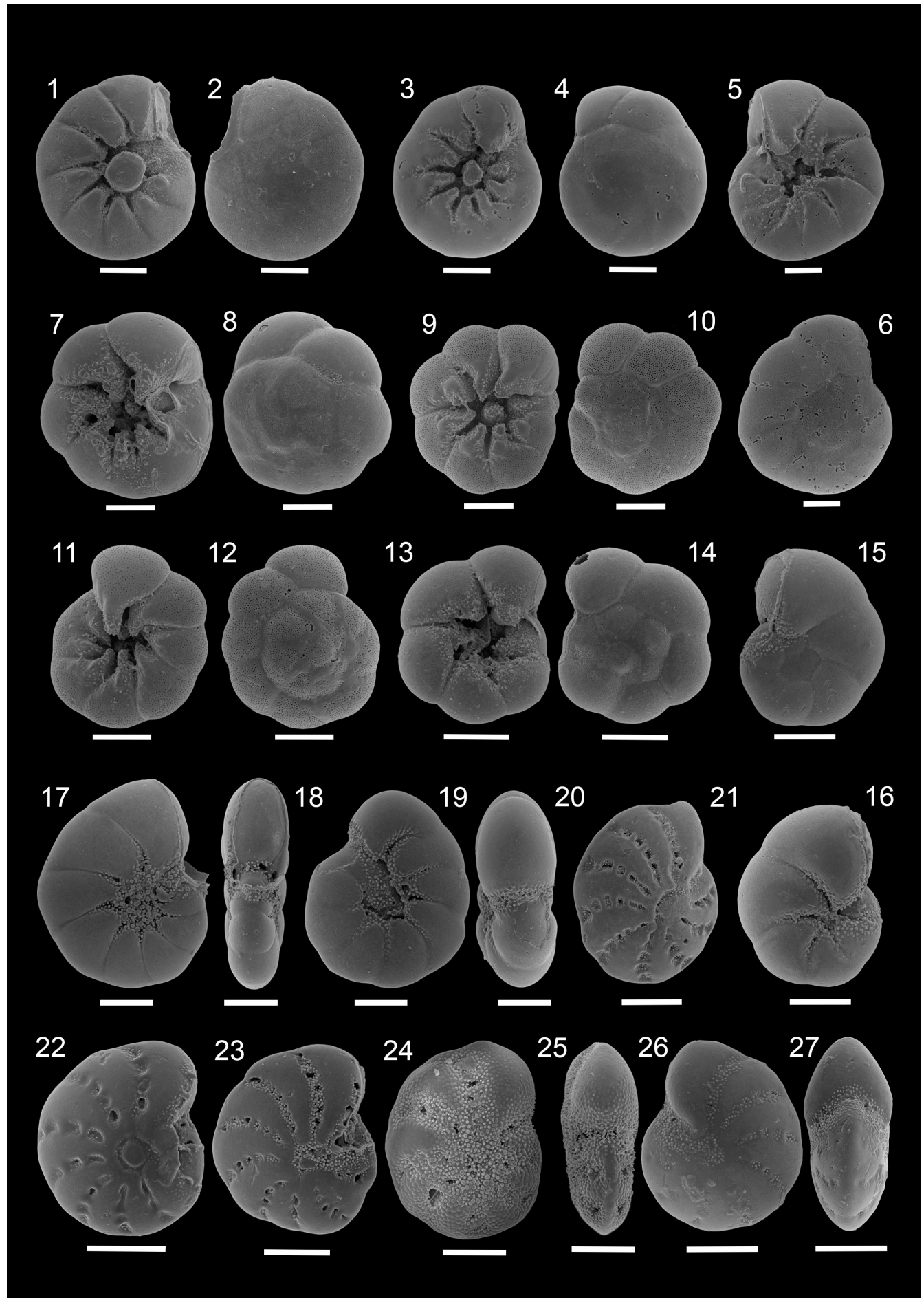

Plate 1. SEM photomicrographs of some of the most common benthic foraminiferal species found in the studied succession. Scale bar $=100 \mu \mathrm{m}$. (1-2) Ammonia parkinsoniana (sobrina-type), 162.50 m. (1) Umbilical side. (2) Spiral side. (3-4) Ammonia parkinsoniana, 162.50 m. (3) Umbilical side. (4) Spiral side. (5-6) Ammonia tepida-A. parkinsoniana intermediate morphotype C, $162.50 \mathrm{~m}$. (5) Umbilical side. (6) Spiral side. (7-8) Ammonia tepida-A. parkinsoniana intermediate morphotype B, 162.50 m. (7) Umbilical side. (8) Spiral side. (9-10) Ammonia tepida-A. parkinsoniana intermediate morphotype A, $162.50 \mathrm{~m}$. (9) Umbilical side. (10) Spiral side. (11-14) Ammonia tepida, 162.50 m. (11, 13) Umbilical side. (12, 14) Spiral side. (15-16) Aubignyna perlucida, 163.20 m. (15) Spiral side. (16) Umbilical side. (17-18) Haynesina depressula, 162.50 m. (17) Side view. (18) Peripheral view. (19-20) Haynesina germanica, 162.50 m. (19) Side view. (20) Peripheral view. (21) Elphidium advenum, $162.70 \mathrm{~m}$. Side view. (22) Elphidium clavatum, 163.05 m. Side view. (23) Elphidium gerthi, 162.50 m. Side view. (24-25) Elphidium sp. 1, 163.20 m. (24) Side view. (25) Peripheral view. (26-27) Elphidium sp. 2, 161.30 m. (26) Side view. (27) Peripheral view. 


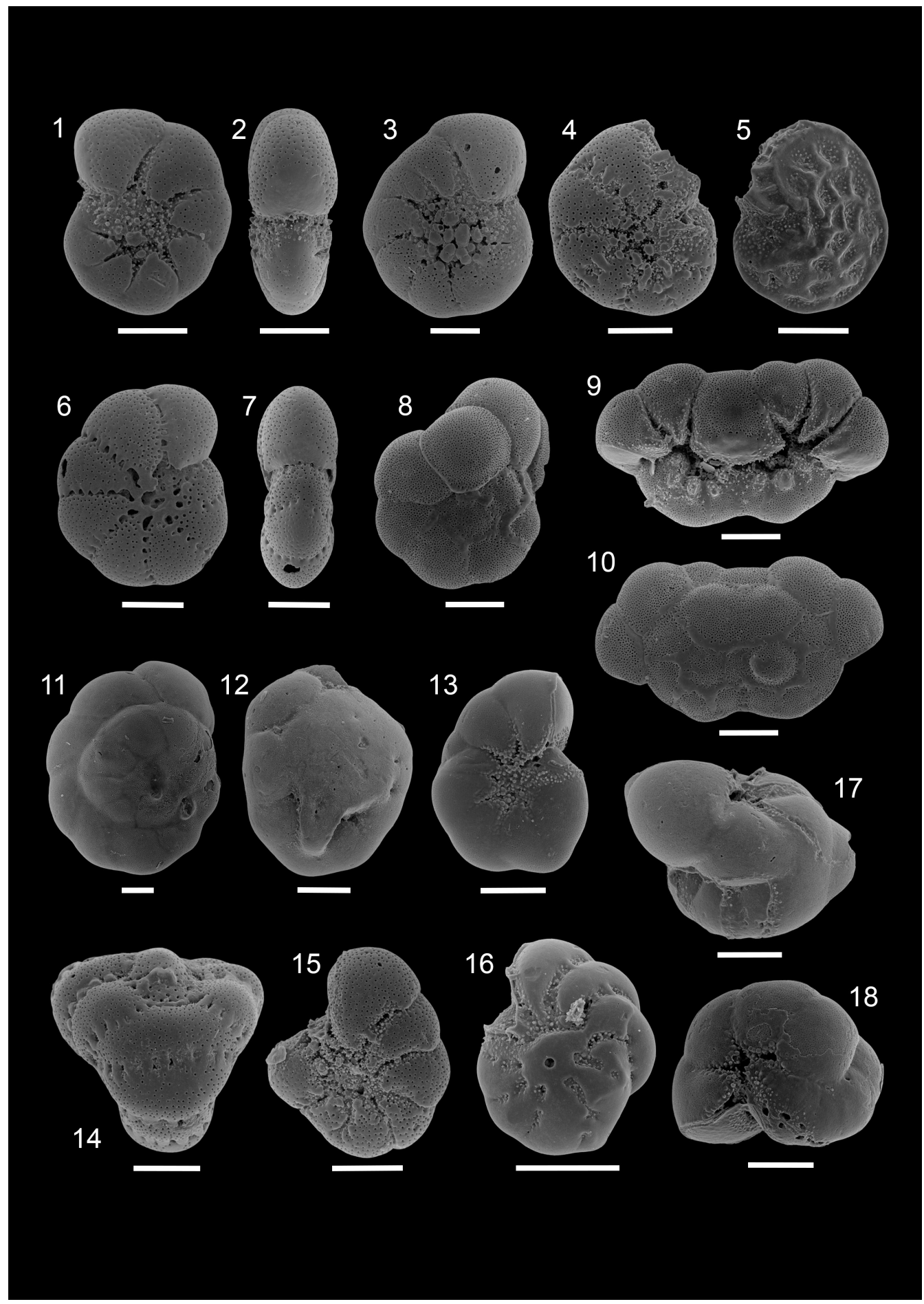

Plate 2. SEM photomicrographs of selected Elphidiidae and individuals affected by morphological abnormalities of the test. Scale bar $=100 \mu \mathrm{m}$. (1-2) Cribroelphidium granosum, 163.05 m. (1) Side view. (2) Peripheral view. (3) Cribroelphidium lidoense, $162.50 \mathrm{~m}$. Side view. (4) Cribroelphidium oceanense, $162.70 \mathrm{~m}$. Side view. (5) Parrellina verriculata, $161.30 \mathrm{~m}$. Side view. (6-7) Cribroelphidium poeyanum, 162.50 m. (6) Side view. (7) Peripheral view. (8) Ammonia tepida-A. parkinsoniana intermediate morphotype A, $162.50 \mathrm{~m}$. Change in coiling direction. (9-10) Ammonia tepida, 161.75 m. Twinned tests. (9) Umbilical side. (10) Spiral side. (11) Ammonia tepida-A. parkinsoniana intermediate morphotype B, $160.95 \mathrm{~m}$. Change in coiling direction and anomalous protuberances on the spiral side. (12) Ammonia parkinsoniana, $163.40 \mathrm{~m}$. Non-developed test. (13) Haynesina germanica, $163.20 \mathrm{~m}$. Change in coiling direction. (14) Cribroelphidium oceanense, $162.50 \mathrm{~m}$. Complex form. (15) Cribroelphidium oceanense, $163.20 \mathrm{~m}$. Abnormal protruding chamber. (16) Elphidium clavatum, $163.20 \mathrm{~m}$. Aberrant chamber shape. (17) Aubignyna perlucida, $162.50 \mathrm{~m}$. Twinned tests. (18) Haynesina germanica, $162.50 \mathrm{~m}$. Twinned tests. 


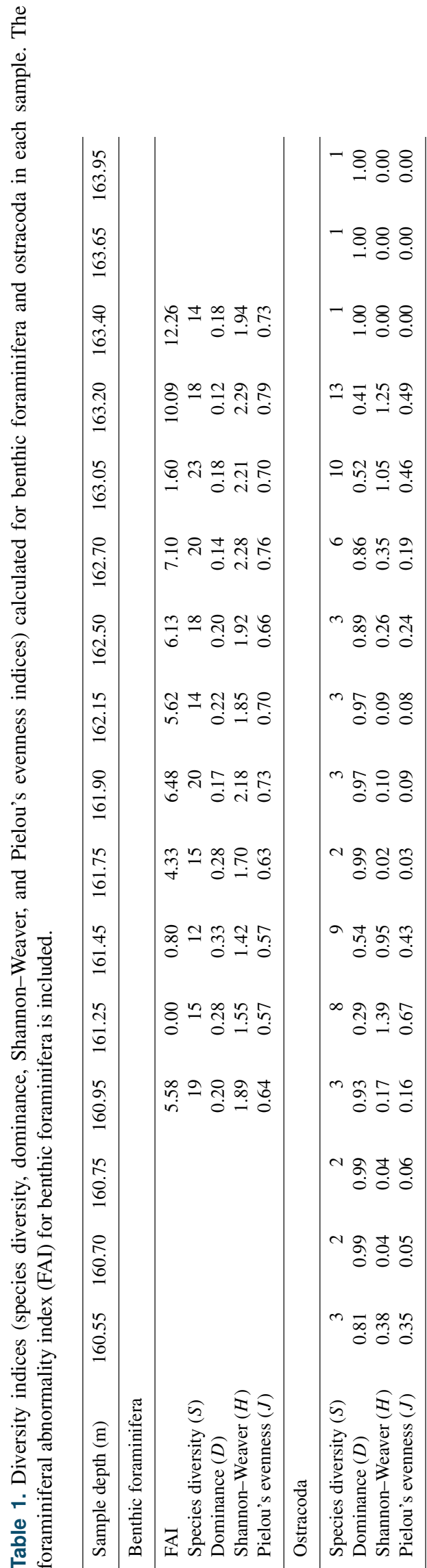

Morphological abnormalities, mainly observed in transitional individuals of A.tepida-A. parkinsoniana, C. oceanense, and $H$. germanica (Table S1), have been recorded in all samples, except at $161.25 \mathrm{~m}$ core depth. The average value of FAI recorded in the studied succession is 5.45 and reaches the maximum at $163.40 \mathrm{~m}$ core depth (12.26). Following the literature (Yanko et al., 1994; Coccioni, 2000), different types of test abnormalities have been recognized: abnormal protruding chambers, abnormal additional chambers, distorted chamber arrangement, change in coiling direction, twinned tests, and non-developed tests. Some individuals exhibit two or even more test abnormalities, resulting in complex forms, sometimes difficult to recognize (Plate 2).

The Q-mode cluster analysis performed on the benthic foraminifera dataset allows us to distinguish two main groups of samples (Fig. 2a). ANOSIM analysis confirms the presence of significant differences in species composition between groups of samples recognized by the Q-mode cluster analysis $(R=0.982, p=0.0173$; Table 2$)$. SIMPER analysis evidences that more than $50 \%$ of differences between clusters are defined by four major groups of benthic foraminifera (Table 3), with the dominant contribution of the abundance of deformed specimens, followed by $C$. $g r a-$ nosum, $C$. oceanense, E. clavatum, and other less common species of Elphidium and Cribroelphidium (Cribroelphidium lidoense, Elphidium gerthi, Elphidium sp. 1, and Elphidium sp. 2; see the taxonomic section for descriptions). Cluster A is mainly defined by the high occurrence of abnormal individuals and the significant presence of $C$. granosum, $C$. oceanense, E. clavatum, Cribroelphidium poeyanum, and other species of Elphidium and Cribroelphidium. In contrast, cluster $\mathrm{B}$ is characterized by a very low occurrence of aberrant specimens, a lower number of Elphidiidae and A. perlucida and slightly higher frequencies of Miliolidae (represented by Adelosina cliarensis, Miliolinella sp., Quinqueloculina seminula , and Triloculina trigonula). Ammonia parkinsoniana, A. tepida (and related morphotypes), and H. germanica represent some of the most common taxa in both clusters (Table 4) and they do not substantially contribute to the main differences between them. A very low contribution is also provided by Asterigerinata mamilla and Haynesina depressula. The one-way ANOSIM performed on diversity indices reveals significant variations in $D, H, J$, and for crossed diversity indices between assemblages (Table 2).

\subsection{Ostracod diversity and assemblages}

The 16 samples analysed for Ostracoda included 5013 ostracod valves from 19 taxa (Table S2). Some of the most common or peculiar taxa are reported in Plate 3.

The number of recorded ostracod species per sample $(S)$ ranges from 1 (samples at $163.40,163.65$, and $163.95 \mathrm{~m}$ core depth) to 13 (163.20 m depth, Table 1). As a consequence, $D$ shows the maximum value of 1 in samples 163.40, 163.65, and $163.95 \mathrm{~m}$ core depth and it reaches a minimum of 0.29 


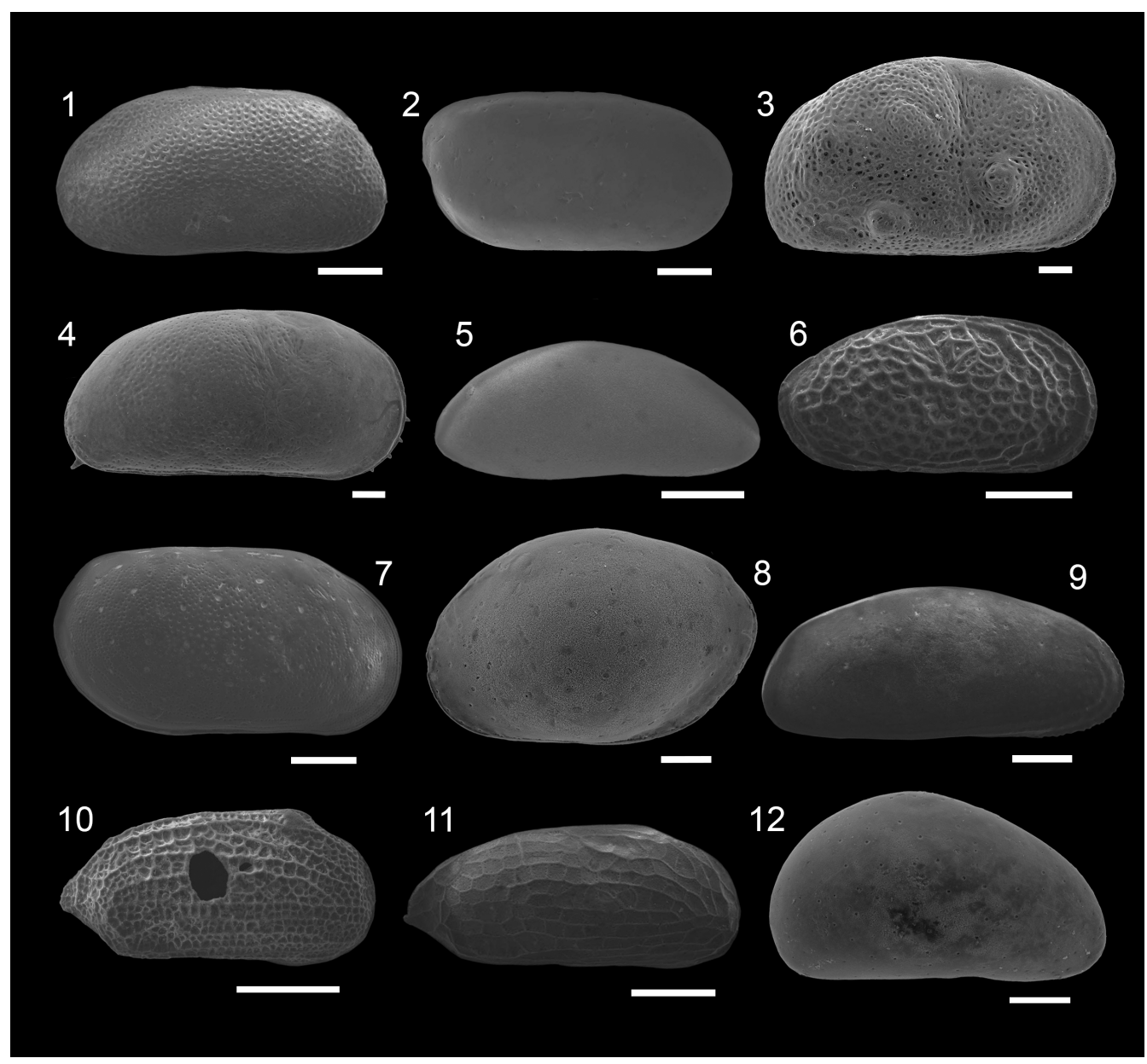

Plate 3. SEM photomicrographs of the most common or peculiar ostracod taxa found in the studied succession. Scale bar $=100 \mu \mathrm{m}$. (1) Pseudocandona sp., juvenile LV, $160.55 \mathrm{~m}$. (2) Basslerites berchoni, RV, $163.05 \mathrm{~m}$. (3) Cyprideis torosa, noded RV, 163.65 m. (4) Cyprideis torosa, un-noded RV, 162.50 m. (5) Cytherois fischeri, RV, 161.45 m. (6) Leptocythere bacescoi, RV, 161.25 m. (7) Loxoconcha elliptica, RV, 160.95 m. (8) Loxoconcha stellifera, LV, 161.45 m. (9) Pontocythere turbida, RV, 161.75 m. (10) Semicytherura reticulata, RV, 161.25 m. (11) Semicytherura cf. sulcata, RV, 163.05 m. (12) Xestoleberis dispar, RV, 161.25 m.
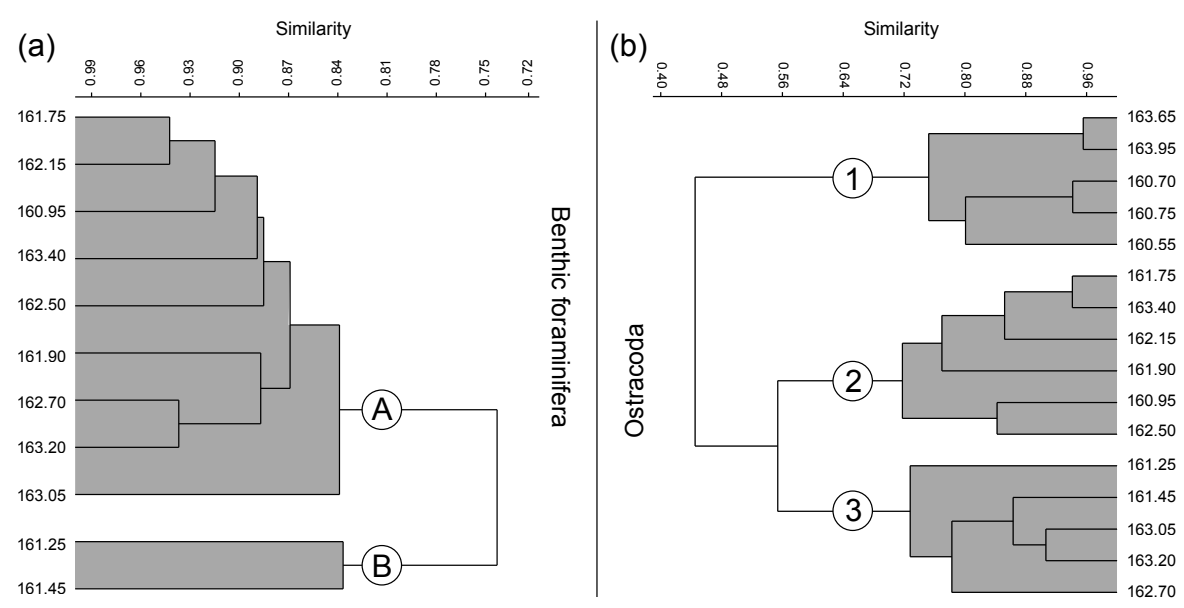

Figure 2. Dendrogram classification from the Q-mode cluster analysis using the Bray-Curtis distance on (a) benthic foraminifera and (b) ostracoda. 
Table 2. Results of the one-way ANOSIM analysis based on diversity indices (Euclidean distance) and faunal composition (Bray-Curtis distance) between the two benthic foraminiferal and the three ostracod assemblages defined by Q-mode cluster analysis (Fig. 2).

\begin{tabular}{lrr|rr}
\hline & \multicolumn{2}{c}{ Benthic foraminifera } & \multicolumn{2}{c}{ Ostracoda } \\
\cline { 2 - 5 } & $R$ & $p$ & $R$ & $p$ \\
\hline$D$ & 0.6982 & $0.0377^{\mathrm{a}}$ & 0.4403 & $0.0009^{\mathrm{b}}$ \\
$H$ & 0.7072 & $0.0219^{\mathrm{a}}$ & 0.4587 & $0.0014^{\mathrm{b}}$ \\
$J$ & 0.7237 & $0.0143^{\mathrm{a}}$ & 0.3923 & $0.0028^{\mathrm{b}}$ \\
$D \times H \times J$ & 0.7132 & $0.0149^{\mathrm{a}}$ & 0.4467 & $0.0008^{\mathrm{b}}$ \\
Faunal composition & 0.982 & $0.0173^{\mathrm{a}}$ & 0.9429 & $0.0001^{\mathrm{b}}$ \\
\hline
\end{tabular}

${ }^{\mathrm{a}}$ and ${ }^{\mathrm{b}}$ indicate significant values of $p<0.05$ and $p<0.01$, respectively.

Table 3. Similarity percentage (SIMPER) analysis performed on benthic foraminiferal assemblages defined by Q-mode cluster analysis (Fig. 2a). Overall average dissimilarity: 25.7.

\begin{tabular}{|c|c|c|c|c|c|}
\hline Taxon & Average dissimilarity & Contribution (\%) & Cumulative (\%) & Cluster A & Cluster B \\
\hline Deformed specimens & 3.76 & 14.63 & 14.63 & 1.40 & 0.30 \\
\hline Cribroelphidium granosum & 3.30 & 12.83 & 27.46 & 1.35 & 0.39 \\
\hline Cribroelphidium oceanense & 3.10 & 12.07 & 39.53 & 0.91 & 0.00 \\
\hline Elphidium clavatum & 2.46 & 9.56 & 49.09 & 0.72 & 0.00 \\
\hline Other Elphidium, Cribroelphidium & 2.10 & 8.17 & 57.26 & 1.01 & 0.39 \\
\hline Cribroelphidium poeyanum & 1.79 & 6.95 & 64.21 & 0.67 & 0.15 \\
\hline Miliolidae & 1.59 & 6.20 & 70.41 & 0.25 & 0.54 \\
\hline Elphidium advenum & 1.22 & 4.74 & 75.15 & 0.78 & 0.54 \\
\hline Aubignyna perlucida & 1.17 & 4.54 & 79.69 & 1.54 & 1.21 \\
\hline A. tepida-A. parkinsoniana morphotypes & 1.00 & 3.90 & 83.59 & 2.07 & 2.33 \\
\hline Asterigerinata mamilla & 0.95 & 3.70 & 87.29 & 0.28 & 0.00 \\
\hline Haynesina germanica & 0.88 & 3.43 & 90.72 & 1.72 & 1.81 \\
\hline Ammonia tepida & 0.88 & 3.42 & 94.14 & 1.46 & 1.40 \\
\hline Ammonia parkinsoniana & 0.82 & 3.20 & 97.33 & 1.87 & 2.05 \\
\hline Haynesina depressula & 0.69 & 2.67 & 100.00 & 1.06 & 1.08 \\
\hline
\end{tabular}

at $161.25 \mathrm{~m}$ core depth. In the same sample, $H$ has the maximum value (1.39), whereas the minimum (0) is recorded in samples with only one species. In samples at $163.40,163.65$ and $163.95 \mathrm{~m}$ core depth $J$ has the value of 0 , whereas it reaches 0.67 at $161.25 \mathrm{~m}$ core depth.

Ostracoda are largely dominated by Cyprideis torosa (87.59\% on average). Other species are mainly represented by Xestoleberis dispar (6.34\%), Loxoconcha stellifera $(2.99 \%)$, and Pontocythere turbida $(1.02 \%)$.

The Q-mode cluster analysis performed on the ostracod fauna reveals the presence of three groups of samples (Fig. 2b) with significantly different faunal composition, as confirmed by ANOSIM $(R=0.9429, p=0.0001$; Table 2). The SIMPER analysis (Table 5) shows that more than $50 \%$ of the difference between clusters is defined by noded C. torosa ( $25.96 \%$ of relative contribution), L. stellifera $(18.92 \%)$, and X. dispar $(18.14 \%)$, followed by lower contributions of Pontocythere turbida $(10.03 \%)$, un-noded $C$. torosa (6.13\%), Leptocythere bacescoi (5.92\%), and Candona sp. $(5.82 \%)$. Cluster 1 is dominated by noded and un-noded $C$. torosa. Relatively low numbers of Pseudocan- dona sp. and Candona sp. are recorded only in this cluster (specifically, within the upper samples at 160.75, 160.70, and $160.55 \mathrm{~m}$ core depth). Un-noded $C$. toros $a$ dominates cluster 2 , followed by very low frequencies of $X$. dispar and L. stellifera recorded in scattered samples. Although cluster 3 is still dominated by un-noded $C$. torosa, it includes high concentrations of several other species, such as X. dispar, L. stellifera, P. turbida, L. bacescoi, and Basslerites berchoni (Table 6). The results of ANOSIM performed on diversity indices indicate highly significant differences (with $p<0.01$ ) in the ostracod assemblages between $D, H, J$, and crossed indices (Table 2).

\subsection{Stratigraphy and distribution of microfossil assemblages}

The lower stratigraphic portion of core $223 \mathrm{~S} 12$ is composed of finely grained, alluvial deposits completely barren in microfossils with scattered layers of fine sand (Fig. 3; Amorosi et al., 1999b). From 163.95 to $163.50 \mathrm{~m}$ core depth, ostracod assemblage 1 occurs and includes very high proportions of 


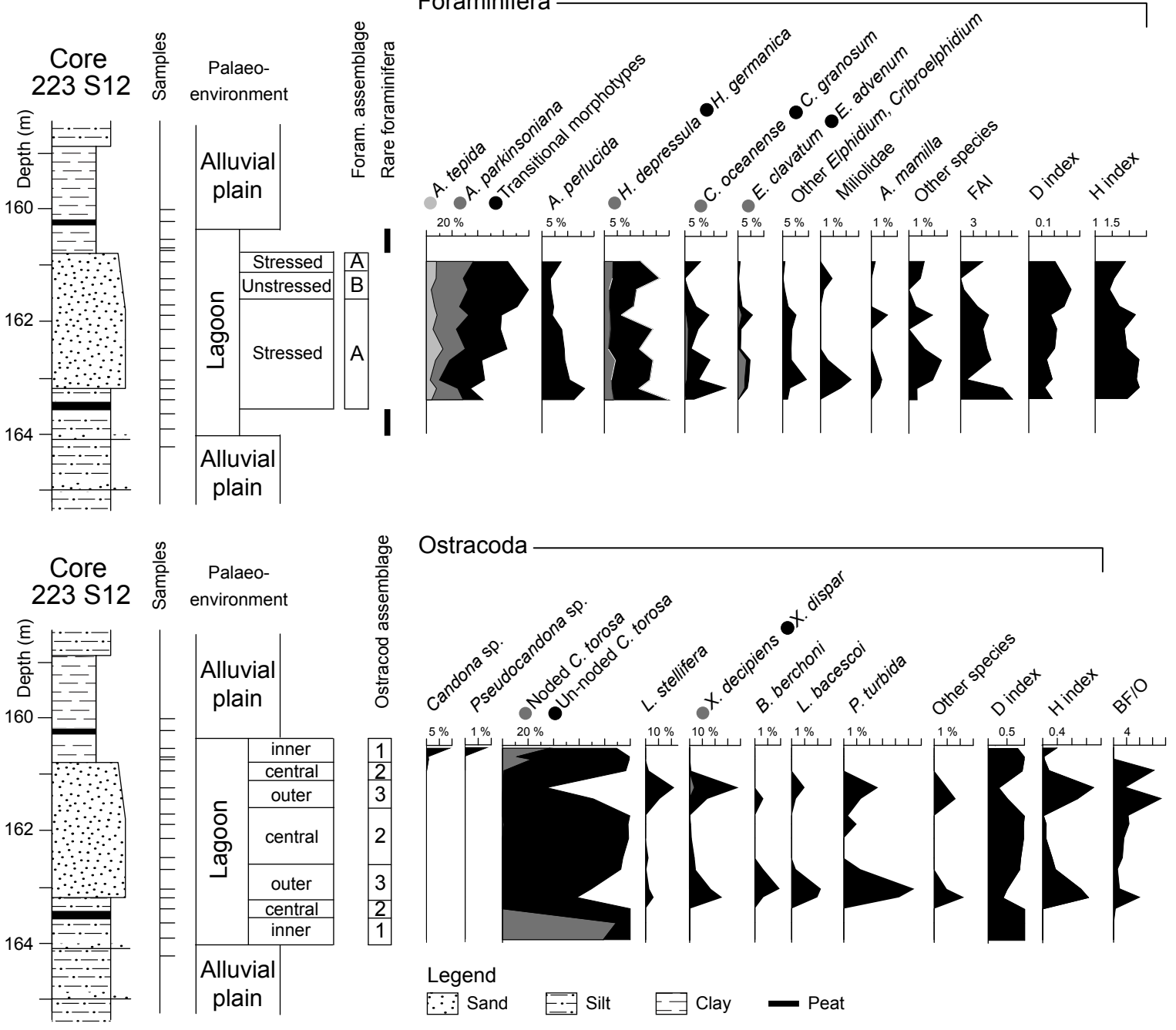

Figure 3. Stratigraphy and vertical distribution of benthic foraminifera and ostracoda in the studied interval of core $223 \mathrm{~S} 12$. Curves represent the relative frequency of major benthic foraminiferal and ostracod taxa, FAI index, diversity indices, and the quantitative ratio between benthic foraminifera and ostracoda $(\mathrm{BF} / \mathrm{O})$.

noded $C$. torosa, whereas benthic foraminifera are extremely rare and include mainly small specimens of $A$. tepida-A. parkinsoniana. Above this interval, benthic foraminifera become abundant, represented by assemblage A, whereas ostracoda are characterized by assemblage 2 , entirely composed of un-noded specimens of $C$. torosa. A major shift in lithology and in the composition of ostracod fauna occurs at $163.30 \mathrm{~m}$ core depth, where clayey silt sediments are replaced by fine sands. This interval is characterized by ostracod assemblage 3, which is replaced by ostracod assemblage 2 at $162.60 \mathrm{~m}$ core depth. From $161.60 \mathrm{~m}$ core depth, both fossil groups mark a change in faunal composition, as benthic foraminifera shifts from assemblage A to assemblage B and ostracoda from assemblage 2 to assemblage 3. Benthic foraminifera of assemblage A and ostracoda of assemblage 2 are recorded again within the following stratigraphic interval, from 161.10 to $160.80 \mathrm{~m}$ core depth. Upward, clayey sediments include scattered individuals of A. tepida-A. parkinsoniana, whereas ostracoda are abundant and represented by assemblage 1. Above a thick peat layer at $160.50 \mathrm{~m}$ core depth, clay and silts of alluvial plain (Amorosi et al., 1999b) are barren in microfossils.

\section{Discussion}

\subsection{Benthic foraminiferal assemblages}

Both assemblages are dominated by euryhaline taxa, such as A. parkinsoniana, A. tepida, and $H$. germanica, which suggest the development of a brackish lagoon environment. These taxa dominate lagoons, coastal lakes, and estuaries, where salinity, oxygen, organic matter, and nutrients rapidly change (Alve and Murray, 1994; Stouff et al., 1999). Specif- 
Table 4. Mean values of relative abundances of selected taxa, FAI, and diversity indices for benthic foraminiferal assemblages identified using cluster analysis.

\begin{tabular}{lrr}
\hline \multicolumn{1}{c}{ Benthic foraminifera } & & \\
Assemblage & $\mathrm{A}$ & $\mathrm{B}$ \\
\hline Ammonia parkinsoniana & 18.68 & 24.83 \\
Ammonia tepida & 6.96 & 5.66 \\
A. tepida-A. parkinsoniana morphotypes & 27.81 & 45.94 \\
Asterigerinata mamilla & 0.36 & 0.00 \\
Aubignyna perlucida & 8.91 & 3.36 \\
Cribroelphidium granosum & 6.16 & 0.67 \\
Cribroelphidium lidoense & 0.09 & 0.13 \\
Cribroelphidium oceanense & 0.67 & 0.00 \\
Cribroelphidium poeyanum & 1.13 & 0.13 \\
Elphidium advenum & 1.58 & 0.58 \\
Elphidium clavatum & 1.54 & 0.00 \\
Elphidium gerthi & 0.23 & 0.00 \\
Elphidium sp. 1 & 2.10 & 0.13 \\
Elphidium sp. 2 & 0.09 & 0.09 \\
Haynesina depressula & 2.70 & 2.47 \\
Haynesina germanica & 12.66 & 14.32 \\
Miliolidae & 0.28 & 0.39 \\
\hline FAI & 6.58 & 0.40 \\
Dominance (D) & 0.19 & 0.31 \\
Shannon-Weaver $(H)$ & 2.03 & 1.49 \\
Pielou's evenness $(J)$ & 0.71 & 0.57 \\
\hline & & \\
\hline
\end{tabular}

ically, A. parkinsoniana is common in the northern Adriatic lagoons of Venice (Coccioni et al., 2009), Marano, and Grado (Melis and Covelli, 2013) and also in the Goro lagoon of the Po River delta (Fig. 1; Coccioni, 2000). Ammonia tepida is a widespread species dominant in lagoons, estuaries, and deltaic environments (Jorissen, 1988; Murray, 2006), commonly recorded in central lagoonal assemblages of the Mediterranean associated with $\mathrm{H}$. germanica (Debenay et al., 2000). The latter taxon prefers to feed on labile organic matter, such as diatoms, in contrast to A. tepida, which is able to consume many food sources, including refractory material (Goldstein and Corliss, 1994; de Nooijer et al., 2007).

The observed foraminiferal distribution is substantially comparable with that present today in the Goro lagoon (Fig. 1; Coccioni, 2000), a brackish-water area with an average depth of ca. $1.5 \mathrm{~m}$, showing remarkable local and seasonal variations in physico-chemical parameters (salinity: $11.7-31 \%$; temperature: $4.2-27.5^{\circ} \mathrm{C}$; oxygen: $3.7-$ $12.4 \mathrm{mg} \mathrm{L}^{-1}$ ) of the bottom water. In this lagoon, the frequencies of A. parkinsoniana, A. tepida, and related morphotypes (from 16 to $84 \%$ of total assemblage, average $52 \%$ ) are not clearly linked with the sample position within the lagoon. A similar pattern is also shown by other abundant species, such as $H$. germanica and $C$. oceanense (listed as C. gunteri in Coccioni, 2000). Similar to the assemblages of core $223 \mathrm{~S} 12$, foraminifera with morphological abnormali- ties are common, but their presence in the Goro lagoon is mainly attributed to heavy metal contamination; in the succession analysed, the distribution of these peculiar specimens is the main factor for the distinction of two clusters, defining assemblages A and B (Fig. 2a).

\subsubsection{Stressed assemblage (assemblage A)}

The concentration of abnormal individuals (FAI) is relatively high (6.58 on average) and exceeds 1 in all samples of the assemblage, which is considered the threshold value between stressed and unstressed populations from literature sources (Alve, 1991; Frontalini and Coccioni, 2008). Benthic foraminifera exposed to extreme values of salinity, oxygen deficiency, high concentrations of nutrients, or contaminants show frequencies of deformed tests always $>1 \%$, whereas the occurrence of benthic foraminiferal abnormalities under normal conditions is always lower (Stouff et al., 1999; Le Cadre and Debenay, 2006). Therefore, the high FAI recorded in the samples studied can be considered indicative of palaeoenvironmental stress, likely resulting from rapid oscillations in physico-chemical parameters such as salinity and oxygen concentration at the bottom. This is in accordance with other studies performed on benthic foraminiferal assemblages that interpret the high occurrence of abnormal specimens within transitional palaeoenvironments as a consequence of reduced, fluctuating salinity (Bik, 1964; Wang et al., 1985), oxygen depletion (Alve, 1991), or both (Geslin et al., 2002). Nevertheless, the contribution of other adverse ecological parameters could not be excluded since communities with high numbers of deformed tests generally result from the interplay of multiple environmental factors (Scott and Medioli, 1980; Boltovskoy et al., 1991).

Similar values of relatively low dominance $(0.19$ on average) and high diversity ( $H$ value of 2.03 on average) recorded for this assemblage are reported from inner to outer portions of Adriatic and Tyrrhenian brackish-water environments (Carboni et al., 2009; Melis and Covelli, 2013).

The distribution of $H$. germanica and A. tepida suggests relatively high nutrient inputs, represented by labile and refractory organic matter. Ample food availability (and possibly low oxygen concentration) is confirmed by the relatively high frequencies of $A$. perlucida, $C$. granosum, and $C$. poeyanum, which typically live in shallow marine environments with substrates enriched in organic matter and limited oxygen deficiency (Jorissen, 1988). These Cribroelphidium species are considered stressed and tolerant forms, in contrast to their unstressed counterparts represented by $C$. $l i$ doense and $C$. decipiens, more abundant on substrates with low organic matter content (Jorissen, 1988). In addition to these taxa, a wide variety of Elphidium and Cribroelphidium species are recorded almost exclusively within this assemblage and greatly contribute to the increase in interspecific diversity. In detail, Cribroelphidium oceanense is a brackishwater species, common in shallow Mediterranean lagoons 
Table 5. Similarity percentage (SIMPER) analysis for ostracod assemblages defined with Q-mode cluster analysis (Fig. 2b). Overall average dissimilarity: 45.35 .

\begin{tabular}{lrrrrrr}
\hline Taxon & $\begin{array}{r}\text { Average } \\
\text { dissimilarity }\end{array}$ & $\begin{array}{r}\text { Contribution } \\
(\%)\end{array}$ & $\begin{array}{r}\text { Cumulative } \\
(\%)\end{array}$ & $\begin{array}{r}\text { Cluster 1 } \\
\text { Cluster 2 }\end{array}$ & Cluster 3 \\
\hline Noded C. torosa & 13.41 & 25.96 & 25.96 & 2.08 & 0.23 & 0.06 \\
Loxoconcha stellifera & 9.77 & 18.92 & 44.87 & 0.00 & 0.35 & 1.81 \\
Xestoleberis dispar & 9.37 & 18.14 & 63.02 & 0.00 & 0.48 & 1.69 \\
Pontocythere turbida & 5.18 & 10.03 & 73.05 & 0.00 & 0.15 & 0.95 \\
Un-noded C. torosa & 3.17 & 6.13 & 79.18 & 2.09 & 2.48 & 2.28 \\
Leptocythere bacescoi & 3.06 & 5.92 & 85.10 & 0.00 & 0.00 & 0.59 \\
Candona sp. & 3.01 & 5.82 & 90.92 & 0.51 & 0.00 & 0.00 \\
Basslerites berchoni & 2.51 & 4.86 & 95.78 & 0.00 & 0.00 & 0.46 \\
Xestoleberis decipiens & 1.32 & 2.55 & 98.33 & 0.00 & 0.00 & 0.28 \\
Pseudocandona sp. & 0.86 & 1.67 & 100.00 & 0.16 & 0.00 & 0.00 \\
\hline
\end{tabular}

Table 6. Mean ostracod assemblages' parameters and relative frequencies of major taxa.

\begin{tabular}{lrrr}
\hline \multicolumn{4}{c}{ Ostracoda } \\
Assemblage & 1 & 2 & 3 \\
\hline Noded C. torosa & 47.94 & 0.43 & 0.07 \\
Un-noded C. torosa & 49.66 & 98.05 & 65.15 \\
Candona sp. & 2.07 & 0.00 & 0.00 \\
Pseudocandona sp. & 0.33 & 0.00 & 0.00 \\
Basslerites berchoni & 0.00 & 0.00 & 0.78 \\
Loxoconcha stellifera & 0.00 & 0.80 & 8.59 \\
Leptocythere bacescoi & 0.00 & 0.00 & 1.17 \\
Xestoleberis decipiens & 0.00 & 0.00 & 0.86 \\
Xestoleberis dispar & 0.00 & 1.07 & 19.00 \\
Pontocythere turbida & 0.00 & 0.22 & 3.00 \\
Semicytherura spp. & 0.00 & 0.00 & 0.25 \\
\hline Dominance $(D)$ & 0.96 & 0.96 & 0.52 \\
Shannon-Weaver $(H)$ & 0.09 & 0.11 & 1.00 \\
Pielou's evenness $(J)$ & 0.16 & 0.12 & 0.45 \\
\hline
\end{tabular}

and coastal lakes (Debenay et al., 2000; Carboni et al., 2009; Frontalini et al., 2009). This taxon is particularly abundant in eutrophic areas characterized by high concentrations of nutrients and variations in salinity (Melis and Covelli, 2013). Elphidium advenum lives in coastal areas and it is recorded in low percentages in the Mediterranean lagoons (Albani and Serandrei Barbero, 1990; Hohenegger et al., 1993). Elphidium clavatum and E. gerthi are usually found in low-salinity waters, such as estuaries, outer lagoons, and marginal marine environments strongly influenced by fluvial inputs (Murray, 2006). Moreover, E. clavatum is an opportunistic species, able to tolerate high sediment and nutrient inputs, also in oxygen-depleted conditions (Linke and Lutze, 1993; Alve and Murray, 1999).

Summarizing, the composition of foraminiferal assemblage $\mathrm{A}$ is indicative of a brackish lagoon with substantially stressed conditions, possibly produced by strong variations in salinity and oxygen. This assemblage is considered to reflect a palaeoenvironment comparable with the recent Goro lagoon, probably with higher organic matter and lower oxygen concentration as revealed by the frequencies of species indicative of these conditions (such as A. perlucida, C. granosum, C. poeyanum, and C. oceanense).

\subsubsection{Unstressed assemblage (assemblage B)}

This assemblage shows a significantly lower number of aberrant specimens (FAI values $<1$ ); this concentration is in agreement with the number of abnormal individuals naturally present within benthic foraminifera populations, as revealed by laboratory studies (Stouff et al., 1999). Compared with assemblage A, it also includes a lower number of species indicative of high nutrient inputs and low oxygenated bottom water, such as selected Cribroelphidium, Elphidium, and A. perlucida. The substantially lower concentrations of these taxa, mainly replaced by morphotypes of A. tepida and A. parkinsoniana, are responsible for the differences in faunal composition and community structure between the two assemblages (specifically, higher $D$ and lower $H$ and $J$ values of assemblage B). Therefore, even if assemblage B shows a lower $H$ index, the absence of species related to eutrophic conditions seems to be indicative of a less stressed environment in terms of oxygen conditions.

The palaeoenvironmental interpretation of assemblage B is substantially comparable with that of the previous one; however, the low FAI values are indicative of unstressed conditions in a relatively stable palaeoenvironment, characterized by lower concentrations of organic matter and without oxygen depletion at the bottom.

\subsection{Ostracod assemblages}

All ostracod assemblages are dominated by C. torosa, a widespread, euryhaline taxon, commonly found in transitional environments such as lagoons, estuaries, and inland 
ponds (Athersuch et al., 1989). It is an opportunistic species, able to live from almost freshwater to hypersaline conditions, irrespective of substratum type, vegetation cover, temperature, and oxygen concentration (Meisch, 2000). This species is recorded with very high frequencies in the major northern Adriatic lagoons of Italy, such as Venice, Marano, and Grado (Montenegro and Pugliese, 1996; Ruiz et al., 2000). In accordance with benthic foraminifera, the ostracod fauna dominated by $C$. torosa reflects the development of a lagoonal basin.

Despite the strong dominance of $C$. torosa in the analysed succession, significant differences in composition and ecological structure of ostracod assemblages could be related to the faunal response to changing palaeoenvironmental conditions. In comparison to benthic foraminifera, ostracod assemblages show more significant differences in the community structure (Table 2), indicating that this group reacted with sharp faunal changes to subtle palaeoenvironmental variations not recorded by the other fossil group.

\subsubsection{Inner lagoon assemblage (assemblage 1)}

Cyprideis torosa presents two morphotypes with different ornamentation of the valves, and both of them are recorded within this assemblage: noded and un-noded. The formation of nodes in $C$. torosa is related to salinity and concentration of $\mathrm{Ca}^{2+}$ in the water (Keyser and Aladin, 2004; Frenzel et al., 2012). There is disagreement about the salinity limits proposed for the presence of noded valves. Some authors reported the occurrence of noded valves in waters with salinity of $<14-15$ psu (Marco-Barba, 2010), but it seems that nodes are formed mainly below the switching point of osmotic regulation for C. torosa at ca. 8 psu (Aladin, 1993). High frequencies of noded valves are reported for values of salinity below 2 (Frenzel et al., 2010, 2012) or 5 psu (MarcoBarba, 2010). Since ecophenotypes in C. torosa are likely determined by multiple factors (Van Harten, 2000; Keyser and Aladin, 2004), palaeosalinity estimation based exclusively on morphological variability in $C$. torosa should be carefully used, but it is a useful proxy to detect palaeoenvironmental trends (Pint et al., 2012).

Pseudocandona and Candona are freshwater-mesohaline taxa found only within the uppermost samples, frequent in European ponds and lakes (Meisch, 2000; Pieri et al., 2005).

The very high dominance ( 0.96 on average), paralleled by the low $H$ and $J$ values (on average 0.09 and 0.16 , respectively) suggest restricted palaeoenvironmental conditions.

The co-dominance of noded and un-noded $C$. torosa reflects deposition in a restricted, oligohaline environment, like a low-salinity inner lagoon possibly with oxygen deficiency, where only this opportunistic species is able to thrive. The abundance of noded valves of $C$. torosa is indicative of oligohaline conditions (Frenzel et al., 2012). Un-noded C. torosa associated with lower frequencies of noded valves is reported from specific areas of the Venice Lagoon subject to high freshwater inputs from rivers and urban and industrial activities (Ruiz et al., 2000). The presence of Candona and Pseudocandona in the uppermost samples indicates a consistent contribution of freshwater. Similar ostracod assemblages composed mainly of $C$. torosa and freshwater species are reported from a northern European oligohaline lagoon strongly influenced by river inflows (Pint and Frenzel, 2017).

\subsubsection{Central lagoon assemblage (assemblage 2)}

Assemblage 2 is dominated by un-noded $C$. torosa, the most widespread morphotype of this species in Mediterranean lagoons. The observed concentrations of un-noded $C$. torosa ( $>90 \%)$ are similar to those recorded in the Venice Lagoon, where monospecific assemblages also occur (Ruiz et al., 2000). Very low concentrations of brackish-marine taxa such as X. dispar and L. stellifera are reported from the northern Adriatic lagoons of Venice, Marano, and Grado and could suggest slight influxes of normal saline water (Montenegro and Pugliese, 1996; Ruiz et al., 2000). Ostracod assemblages dominated by un-noded $C$. torosa are also reported from confined lagoons of the Gulf of Lion characterized by extreme euryhalinity (Salel et al., 2016).

The increasing $H$ index in comparison to assemblage 1 can be related to a higher salinity. Dominance is still very high (paralleled by low $J$ index) and suggests variable physico-chemical parameters.

Ostracod assemblage 2 is consistent with a central lagoonal basin, possibly subject to salinity oscillations. The dramatic decrease in noded $C$. torosa, replaced by the unnoded morphotype and the absence of freshwater taxa, indicates an increasing salinity.

\subsubsection{Outer lagoon assemblage (assemblage 3)}

The concentration of the euryhaline $C$. torosa decreases and a great number of species appear. One of the most common taxa is $X$. dispar, a phytal, polyhaline-euhaline species commonly recorded along the Italian coasts and in open lagoons greatly influenced by seawater (Bonaduce et al., 1975; Breman, 1975; Arbulla et al., 2004; Aiello et al., 2006). This assemblage also includes relatively high percentages of $L$. stellifera, a shallow-water species that lives from mesohaline to normal saline waters in lagoons, bays, and slightly freshwater-influenced areas along the Adriatic coast, reaching higher concentrations on vegetated substrates (Bonaduce et al., 1975; Arbulla et al., 2004; Aiello et al., 2006). Other species are less common but recorded almost exclusively within assemblage 3 . Among them, P. turbida typically lives in coastal environments; it is dominant along the Italian shorelines of the Adriatic Sea and also near the fluvial mouths of the Po Delta (Colalongo, 1969; Bonaduce et al., 1975). Leptocythere bacescoi is well distributed along the Adriatic coast of Italy, reported also from the Limsky Channel and Marano and Grado lagoons, from polyhaline to 
euhaline waters (Uffenorde, 1972; Breman, 1975; Montenegro and Pugliese, 1996). Other taxa such as $X$. decipiens, $B$. berchoni, and Cytherois fischeri live in polyhaline-euhaline shallow water environments with vegetated bottoms (Uffenorde, 1972; Bonaduce et al., 1975; Arbulla et al., 2004). Rare specimens of the brackish-water taxon Loxoconcha elliptica and some marine species of the genus Semicytherura (Athersuch et al., 1989) are exclusively recorded within this assemblage.

The maximum diversity ( $H$ index), evenness, and decrease in dominance indicate more favourable palaeoenvironmental conditions for the ostracod fauna, in accordance with an increasing salinity due to the influence of seawater.

The composition of this assemblage is considered to reflect a lagoon highly influenced by normal saline waters, possibly an outer lagoonal area. Brackish-marine taxa characterize this assemblage, and the great abundance of phytal species indicates vegetation cover at the bottom. Ostracod assemblages with high frequencies of $C$. torosa and Xestoleberis are reported from the Venice Lagoon, behind the sand barriers that divide the lagoon from the northern Adriatic Sea (Ruiz et al., 2000), where macroalgae and low hydrodynamic conditions are present. Ostracod assemblages with higher frequencies of marine taxa such as P. turbida and Semicytherura spp. are recorded around the tidal inlets (Ruiz et al., 2000) in areas greatly influenced by seawater.

\subsection{Evolution of the palaeolagoon: the combined approach of benthic foraminifera and ostracoda}

Detailed micropalaeontological analyses performed on benthic foraminifera and ostracoda allow an accurate characterization of the stratigraphic interval. The two microfossil groups provide distinct information, related to specific palaeoenvironmental conditions. The main differences between the benthic foraminiferal assemblages are represented by the FAI and the number of brackish-water species related to high concentrations of nutrients. Accordingly, two assemblages have been defined: (i) a stressed assemblage, formed mainly in response to salinity oscillations accompanied by high organic matter and low oxygen concentrations at the bottom, and (ii) an unstressed assemblage that suggests oxygenated conditions in a more stable palaeoenvironment. Despite the overall lower number of species, ostracod assemblages show higher differences in the community structure and include taxa with specific environmental tolerance ranges, indicative of distinct sub-environments. In this case, the contribution of subordinate freshwater and brackish-marine taxa allowed the definition of inner, central, and outer lagoon assemblages that reflect a distinct salinity gradient.

Above the basal alluvial plain deposits, the great abundance of noded C. torosa (assemblage 1) marks the beginning of transgression and the onset of a strong freshwaterinfluenced inner lagoon, where abundant populations of cal- careous foraminifera cannot be developed mainly due to the extremely low salinity. In these settings agglutinated foraminifera are locally present (e.g. Debenay et al., 2000), but these are not observed in this succession, probably for the low preservation potential of their fragile tests. In this respect, previous work on foraminiferal assemblages of subsurface successions of the Po Plain have shown the rare occurrence of agglutinated foraminifera of the inner lagoon, almost entirely represented by Trochammina inflata, and observed uniquely in Holocene sediments of the upper $20 \mathrm{~m}$ of cored successions (e.g. Amorosi et al., 2004; Fiorini, 2004).

Upward, the superposition of ostracod assemblages 2 and 3 indicates the passage to central and outer lagoon conditions and an increasing salinity. The development of a marineinfluenced lagoon is consistent with the landward migration of a back-barrier system driven by MIS 7 transgression, when the sea level reached a maximum of $-18 \mathrm{~m}$ below the present sea level in the Adriatic area (Dutton et al., 2009). The high occurrence of deformed benthic foraminifera provides evidence for an extremely unstable environment in the palaeolagoon, with thalassic conditions (FAI $<20 \%$; Pint et al., 2017). The maximum FAI value recorded in the first sample including abundant benthic foraminifera $(163.40 \mathrm{~m}$ core depth) is indicative of very stressed conditions possibly related to oxygen depletion and salinity variations, considered important environmental parameters that control the development of test deformities in paralic environments (Geslin et al., 2002). This is also consistent with the monospecific ostracod assemblages, represented by the highly opportunistic taxon C. torosa. However, other disadvantageous palaeoenvironmental parameters could have contributed to the formation of the stressed foraminiferal assemblage.

A drastic reduction of marine-influenced ostracod species (i.e. the onset of assemblage 2) from 162.60 to $161.60 \mathrm{~m}$ core depth is indicative of lower salinity and higher confinement, likely related to a progradation of the lagoon during a reduced rate of sea level rise. The recorded ostracod assemblage with extremely high concentrations (> 90\%) of un-noded $C$. torosa could be indicative of both brackish and hypersaline conditions (Ruiz et al., 2000; Salel et al., 2016; Pint and Frenzel, 2017) in the absence of SEM analysis on sieve pores (Pint et al., 2017); however, the benthic foraminiferal assemblages are consistent with a brackish palaeoenvironment. In detail, hyperhaline environments determine benthic foraminiferal assemblages with a very low diversity, often represented by monospecific populations of A. tepida (Almogi-Labin et al., 1992; Engel et al., 2012). The relatively high diversity of benthic foraminifera within this stratigraphic interval and the common occurrence of selected taxa, such as $H$. germanica and $E$. clavatum, indicate the presence of brackish waters. The high rate of deformed tests can be related to unstable environmental parameters, probably oscillations of salinity derived from freshwater inputs. Nevertheless, species related to bottom water enriched in organic matter (A. perlucida, C. granosum, C. oceanense, 
E. clavatum) are still abundant and suggest that the palaeoecological stress could even be provided by slightly reduced oxygen concentrations. As a whole, ostracoda and benthic foraminifera highlight an episode of more restricted conditions in the lagoon, when the interplay between freshwater and marine inputs created an unstable palaeoenvironment.

A new phase of higher salinity, related to a higher influence of seawater, is recorded by ostracod assemblage 3 between 161.60 and $161.10 \mathrm{~m}$ core depth. The lower proportions of the opportunistic C. torosa, paralleled by the common occurrence of shallow marine ostracoda and the highest value of the ostracod's Shannon and evenness indices at $161.25 \mathrm{~m}$ core depth, are inferred to indicate the maximum marine influence. Benthic foraminifera with a FAI $<1$ (foraminiferal assemblage B) evidence a phase of relatively stable palaeoenvironmental conditions, recorded only within this interval.

Upward, the presence of ostracod assemblage 2 with the high dominance of un-noded $C$. torosa is considered to reflect a lower influence of seawater. At the same time, stressed foraminiferal assemblages indicate unstable palaeoenvironmental conditions likely related to low salinity, high organic matter content, and low oxygen concentrations typical of the innermost portion of Mediterranean coastal lagoons (Alves Martins et al., 2016). In the following samples, a great faunal turnover to oligohaline ostracod assemblages reveals relevant freshwater inputs in a restricted environment, in proximity to the innermost portion of the lagoon. Here, palaeoenvironmental conditions exceeded the tolerance limit for calcareous foraminifera, which disappeared. The relative regressive trend culminates with the deposition of barren sediments of an alluvial plain.

\section{Benthic foraminifera or Ostracoda, the conclusions}

Quantitative palaeontological analyses performed on benthic foraminifera and ostracoda from a relatively short stratigraphic interval attributed to MIS 7 allowed a detailed palaeoenvironmental reconstruction. Specifically, the quantitative approach provided information about the environmental resolution potential for each group of fossils.

The combined application of benthic foraminifera and ostracoda indicates the development of a lagoon subject to minor environmental variations, in response to the interplay of freshwater and marine water inputs. A general transgressiveregressive trend is recorded by ostracod assemblages, with the occurrence of a minor relatively regressive phase. Outer lagoonal, unstressed conditions observed by ostracoda and benthic foraminifera are related to the highest marine influence recorded in the succession.
Both fossil groups contributed to the palaeoenvironmental reconstruction; however, the most accurate environmental resolution is commonly shown by the Ostracoda for their (i) abundant occurrence, (ii) higher differences in the ecological structure of assemblages, and (iii) distinct faunal composition in terms of species with precisely defined tolerance ranges. Scarce or rare taxa greatly contribute to the palaeoenvironmental interpretation, even if assemblages are dominated by opportunistic species. The same characteristics are not accomplished by benthic foraminifera, which show more similar assemblages in this succession. In spite of the higher number of species, they are generally not related to distinctive or quantitatively defined environmental ranges, producing a less precise palaeoenvironmental reconstruction. In addition, benthic foraminifera are not present in inner lagoon deposits (probably for the low preservation potential of agglutinated tests). However, when ostracod fauna is composed almost entirely of un-noded $C$. torosa, the distinction between brackish or hyperhaline settings is provided by the benthic foraminifera.

Benthic foraminiferal assemblages are mainly defined by the abundance of specimens with morphological abnormalities. High concentrations of deformed benthic foraminifera are quite rare in fossil assemblages and are here considered to indicate stressed conditions, possibly produced by oxygen depletion, fluctuation of salinity, and, eventually, other factors that typically characterize transitional environments. Therefore, benthic foraminifera also give indications of palaeoenvironmental stress that are not clearly shown by ostracod assemblages.

In conclusion, it is substantially intuitive that the quantitative approach to both (or even multiple) fossil groups should be preferred in palaeoenvironmental studies. However, if a choice is required between ostracoda and foraminifera within lagoonal successions, we would prefer Ostracoda. This group allows us to obtain more detailed palaeoenvironmental reconstructions with the recognition of subenvironments not recorded by the benthic foraminifera. In contrast, foraminifera provide relevant additional information (i.e. environmental stability) and, locally, an unambiguous interpretation of peculiar ostracod assemblages (i.e. entirely represented by un-noded $C$. torosa).

Data availability. All the data analysed in this paper are available in the tables provided within the paper or in the Supplement. 
Appendix A: Taxonomic descriptions of some species of benthic foraminifera

Elphidiidae, Rotaliidae, and Nonionidae are some of the most common families of benthic foraminifera reported from modern and fossil coastal deposits, from arctic to tropical areas (Murray, 2006). Due to the high morphological variability among individuals of each group, the specific attribution of a taxon is sometimes difficult. Many studies were performed with the aim of clarifying the classification of these taxa from different geographical zones (e.g. Hansen and Lykke-Andersen, 1976; Hayward et al., 1997).

The contribution of recent studies that combine molecular and morphological data (e.g. Holzmann and Pawlowski, 2000; Darling et al., 2016) is a valuable resource. Previously, attribution of some taxa was controversial due to the uncertainty around formae, subspecies, or species. The genetic characterization of benthic foraminifera with similar morphological features offers solutions for this problem.

Within the studied interval, the high morphological differentiation of the above-mentioned groups led us to a detailed taxonomic analysis, following the classification of Loeblich and Tappan (1987). In the case of uncertain attribution between species, varieties, or formae, the contribution of genetic studies on benthic foraminifera has been taken into consideration, mainly for the taxonomy of selected Elphidiidae (Darling et al., 2016).

Family Nonionidae Schultze, 1854

Subfamily Nonioninae Schultze, 1854

Genus Haynesina Banner and Culver, 1978

Haynesina depressula (Walker and Jacob, 1798)

Plate 1, figs. 17-18

1798 Nautilus depressulus Walker and Jacob: p. 641 , pl. 14, fig. 33

1976 Nonion depressulum (Walker and Jacob); Hansen and Lykke-Andersen, p. 21, pl. 19, figs. 36.

1978 Haynesina depressula (Walker and Jacob); Banner and Culver, p. 200, pl. 10, figs. 1-8.

1984 Nonion depressulum (Walker and Jacob); Sgarrella and Barra, p. 88, pl. 4, fig. 16.

1988 Nonion depressulum (Walker and Jacob); Jorissen, p. 23, pl. 2, fig. 7.

1991 Haynesina depressula (Walker and Jacob); Cimerman and Langer, p. 81, pl. 83, figs. 1-4.

1993 Nonion depressulum (Walker and Jacob); Sgarrella and Montcharmont-Zei, p. 238, pl. 24, figs. 3-4.
1997 Haynesina depressula depressula (Walker and Jacob); Hayward et al., p. 98, pl. 19, figs. 4 7.

2001 Nonion depressulum (Walker and Jacob); Fiorini and Vaiani, p. 393, pl. 8, figs. 18-19.

2012 Haynesina depressula (Walker and Jacob); Milker and Schmiedl, p. 112, fig. 25, 17-18.

2013 Haynesina depressula (Walker and Jacob); Melis and Covelli, p. 449, pl. 1, fig. 25.

2016 Haynesina depressula (Walker and Jacob); Darling et al., p. 9, fig. 3, S17.

Description and remarks: Test planispiral, involute, with 8-12 chambers in the last whorl. Rounded to lobate outline, compressed profile, and rounded periphery. Inflated, slightly depressed sutures that gently open near the umbilicus. Relatively wide, star-shaped umbilical area covered by papillae, which are also present in the innermost part of the sutures, along the aperture, and at the base of apertural face. The primary aperture is defined by a row of interiomarginal rounded pores on the last chamber. The test is smooth.

Distribution: It is reported from infralittoral zones of the Mediterranean Sea, in proximity to the river mouths (Sgarrella and Barra, 1984; Jorissen, 1988; Sgarrella and Montcharmont Zei, 1993). This species also occurs in brackish-water environments such as lagoons and coastal lakes (Carboni et al., 2009; Melis and Covelli, 2013).

It is considered not tolerant of heavy metal pollution, preferring clean and sandy substrates (Frontalini and Coccioni, 2008).

Haynesina germanica (Ehrenberg, 1840)

Plate 1, figs. 19-20

1840 Nonionina germanica Ehrenberg: p. 23, pl. 2, fig. 1.

1976 Protoelphidium anglicum Murray; D’Onofrio et al., p. 273, pl. 19, figs. 1-7.

1976 Nonion germanicum (Ehrenberg); Hansen and Lykke-Andersen, p. 21, pl. 19, figs. 7-12.

1978 Haynesina germanica (Ehrenberg); Banner and Culver, p. 191, pl. 5, figs. 1-8; pl. 9, figs. 1$11,15$.

2000 Haynesina germanica (Ehrenberg); Coccioni, p. 78, fig. 3, 22-23.

2013 Haynesina germanica (Ehrenberg); Melis and Covelli, p. 449, pl. 1, fig. 28.

2016 Haynesina germanica (Ehrenberg); Darling et al., p. 9, fig. 3, S16. 
Description and remarks: Test planispirally enrolled, involute, with 6-12 chambers in the last whorl. The outline is lobulate, profile inflated with parallel sides, periphery broadly rounded. Backward curved, slightly depressed sutures becoming more depressed and wide near the umbilical region. Depressed umbilicus occupied by papillae. Umbilical area, depressed sutures, and base of the apertural face ornamented by papillae. A series of interiomarginal pores at the base of the apertural face forms the aperture. Wall smooth.

Haynesina germanica could seem quite similar to $H$. depressula; however, they differ for some morphological features. In particular, $H$. depressula is laterally more compressed (Plate 1, fig. 18) and has chambers that increase in height more rapidly (Plate 1, fig. 17). Consequently, individuals of $H$. depressula are flatter and more elongated compared to the broader tests of $H$. germanica.

In our samples, $H$. germanica shows some morphological abnormalities, such as abnormal additional chambers, change in coiling or distorted chamber arrangement (Plate 2, fig. 13), and twinned tests (Plate 2, fig. 18).

Distribution: This is one of the dominant species in the inner and central portions of Mediterranean lagoons, usually related to freshwater inputs and high-confinement conditions (Debenay et al., 2000; Carboni et al., 2009). It is very common in a wide range of Italian brackish-water environments, including the Po Delta lagoons (D'Onofrio et al., 1976; Coccioni, 2000). This species usually prefers low-salinity waters, within organic-rich clayey bottoms (Melis and Covelli, 2013).

Haynesina germanica is considered a tolerant species to pollution since high percentages of abnormal individuals are reported from lagoonal areas contaminated by heavy metals or urban wastes (Zampi and D'Onofrio, 1986; Coccioni, 2000).

Family Trichohyalidae Saidova, 1981

Genus Aubignyna Margerel, 1970

Aubignyna perlucida (Heron-Allen and Earland, 1913)

Plate 1, figs. 15-16

1913 Rotalia perlucida Heron-Allen and Earland: p. 139, pl. 13, figs. 7-9.

1988 Ammonia perlucida (Heron-Allen and Earland); Jorissen, p. 51, pl. 2, figs. 11-12, pl. 11, figs. 4-5.

1990 Valvulineria perlucida (Heron-Allen and Earland); Albani and Serandrei Barbero, p. 312, pl. 4, figs. 11-12.

2000 Ammonia perlucida (Heron-Allen and Earland); Coccioni, p. 76, fig. 2, 26-28.
2000 Aubignyna perlucida (Heron-Allen and Earland); Murray et al., p. 61, pl. 1, figs. 1-14.

2008 Aubignyna perlucida (Heron-Allen and Earland); Frontalini and Coccioni, p. 409, pl. 1, fig. 7.

Description and remarks: Test low trochospiral, spiral side evolute, umbilical side involute with five to six chambers in the final whorl. Lobate to slightly lobate outline, inflated profile with broadly rounded periphery. Backward curved, slightly depressed sutures, more depressed near the umbilical area. Closed, depressed umbilicus. Fine papillae cover the umbilical area and the basal part of the last chambers. The aperture consists of a thin slit in interiomarginal position, often covered by pustules. The test is smooth and finely perforated.

Aberrant tests of A. perlucida are not commonly recorded in our samples and include some individuals with distorted coiling or twinned tests (Plate 2, fig. 17).

Distribution: Aubignyna perlucida is one of the most common species in the northern Adriatic lagoons, reported from Venice, Goro, Marano, and Grado lagoons (Albani and Serandrei Barbero, 1990; Coccioni, 2000; Melis and Covelli, 2013). It is also recoded south of the Po Delta, where it reaches relatively high concentrations at shallow depths (ca. 15-20 m) (Jorissen, 1988; Donnici and Serandrei Barbero, 2002). This species lives in areas characterized by high organic matter inputs and it shows a limited tolerance for anoxic conditions (Jorissen, 1988).

The common occurrence of deformed specimens of A. perlucida within northern Adriatic polluted lagoons suggests that this taxon is quite sensitive to environmental and anthropogenic stress (Coccioni et al., 2009; Melis and Covelli, 2013).

Family Rotaliidae Ehrenberg, 1839

Subfamily Ammoniinae Saidova, 1981

Genus Ammonia Brünnich, 1772

Ammonia parkinsoniana (d'Orbigny, 1839)

Plate 1, figs. 1-4

1839 Rosalina parkinsoniana d'Orbigny: p. 99, pl. 4, figs. 25-27.

1988 Ammonia parkinsoniana var. parkinsoniana (d'Orbigny), morphotype 5; Jorissen, p. 46, pl. 9, figs. 1-2.

1991 Ammonia parkinsoniana (d'Orbigny); Cimerman and Langer, p. 76, pl. 87, figs. 7-9.

1993 Ammonia parkinsoniana (d'Orbigny); Sgarrella and Montcharmont-Zei, p. 228, pl. 20, figs. 45. 
2000 Ammonia specimen/T9; Holzmann and Pawlowsky, p. 89, pl. 1, fig. 5.

2001 Ammonia parkinsoniana (d'Orbigny); Fiorini and Vaiani, p. 384, pl. 6, figs. 14-15.

2008 Ammonia parkinsoniana (d'Orbigny); Frontalini and Coccioni, p. 409, pl. 1, fig. 5.

2009 Ammonia parkinsoniana (d'Orbigny); Coccioni et al., p. 261, pl. 1, fig. 2.

2012 Ammonia parkinsoniana (d'Orbigny); Milker and Schmiedl, p. 119, fig. 27, 3-4.

Description and remarks: Test low trochospiral, spiral side evolute, umbilical side involute with eight to nine chambers in the final whorl. Circular outline, rounded periphery and un-inflated chambers. Backward curved sutures, generally flush with the test but on the last chambers they can be slightly depressed. The umbilicus is relatively closed and provided with a prominent boss. Primary aperture is a thin slit in interiomarginal position, at the base of the last chamber from the umbilicus to the test periphery. Wall smooth.

Individuals with very large umbilical knobs can be linked to the A. parkinsoniana sobrina type (Rotalia beccarii var. sobrina Shupack, 1934) and are considered within the $A$. parkinsoniana species here (e.g. Jorissen, 1988).

Deformed individuals of $A$. parkinsoniana are quite rare in our samples and they mainly show abnormal protruding chambers or non-developed tests (Plate 2, fig. 12).

Distribution: Ammonia parkinsoniana is one of the most common species along the Italian coasts, dominating the benthic foraminiferal assemblages from 10 to $20 \mathrm{~m}$ water depth in the Adriatic Sea (Jorissen, 1988). It is also common in Mediterranean lagoons and coastal lakes (Carboni et al., 2009; Coccioni et al., 2009).

This species is considered less tolerant to environmental pollution than its counterpart A. tepida, preferring clean and less polluted areas (Frontalini and Coccioni, 2008). However, abnormal specimens are still found with relatively low frequencies in polluted brackish-water environments, which indicates a certain tolerance for stressful conditions (Carboni et al., 2009; Melis and Covelli, 2013).

Ammonia tepida (Cushman, 1926)

Plate 1, figs. 11-14

1926 Rotalia beccarii (Linné) var. tepida Cushman: p. 79, pl. 1.

1987 Ammonia beccarii tepida (Cushman); Jorissen, p. 38, pl. 2, fig. 8 .

1988 Ammonia parkinsoniana (d'Orbigny) var. tepida Cushman, morphotypes 1, 2, 3; Jorissen, p. 46 , pl. 7 , figs. $1-4$, pl. 10 , fig. 1 .

1991 Ammonia tepida (Cushman); Cimerman and Langer, p. 76, pl. 87, figs. 10-12.
1993 Ammonia beccarii var. tepida (Cushman); Sgarrella and Montcharmont-Zei, p. 228, pl. 20, figs. 5-6.

2000 Ammonia parkinsoniana (d'Orbigny) forma tepida Cushman; Coccioni, p. 76, figs. 2, 1-3, 7-9, 16-18.

2001 Ammonia tepida (Cushman); Fiorini and Vaiani, p. 384, pl. 6, figs. 7-8.

2004 Ammonia tepida (Cushman); Hayward et al., p. 256, pl. 2, fig. T; pl. 3, fig. T; pl. 4, fig. T.

2008 Ammonia tepida (Cushman); Frontalini and Coccioni, p. 409, pl. 1, fig. 6 .

2009 Ammonia tepida (Cushman); Coccioni et al., p. 261, pl. 1, fig. 1 .

Description and remarks: Test low trochospiral, spiral side evolute, six to eight chambers visible in the last whorl of the involute umbilical side. The outline is lobate, with strongly inflated chambers and a broadly rounded periphery. Slightly backward curved sutures, slightly depressed and progressively deeper toward the umbilicus. Open umbilicus without knob. A thin slit in the interiomarginal position defines the primary aperture. The test surface is smooth.

Deformities recorded in A. tepida are abnormal protruding chambers, abnormal additional chambers, and twinned tests (Plate 2, figs. 9-10).

Distribution: Ammonia tepida is a widespread, euryhaline species that dominates in estuaries, lagoons, and deltaic environments (Debenay et al., 2000; Murray, 2006). In the Mediterranean area, it can be found from the innermost to the outer portion of lagoons and in the vicinity of river mouths (Jorissen, 1988; Debenay et al., 2000). It is recorded in highly fluvially influenced environments, as it dominates in the innermost part of the Venice Lagoon (Albani and Serandrei Barbero, 1990) and in the river channels that flow into the Marano and Grado lagoons (Melis and Covelli, 2013). Ammonia tepida is also common in the Po Delta lagoons (D’Onofrio et al., 1976; Coccioni, 2000).

This species is known for its great tolerance of high levels of organic matter, reduced or overwhelming salinity, and environmental pollution; therefore, it is considered the most tolerant species of a variety of environmental and anthropogenic stresses (Yanko et al., 1994; Geslin et al., 1998; Almogi-Labin et al., 1992; Frontalini and Coccioni, 2008).
Ammonia tepida-Ammonia parkinsoniana transi- tional morphotypes
Plate 1, figs. 5-10

Description and remarks: Intermediate morphotypes between A. tepida and A. parkinsoniana always occur in our samples and they were classified within the "A. tepida-A. parkinsoniana intermediate morphotypes" group. All of 
them present a low trochospiral test, evolute on the spiral side, involute on the umbilical side, and backward curved sutures. The aperture consists of a slit in interiomarginal position and the wall is smooth. The discriminant characters of transitional morphologies are provided here.

Morphotype A (Plate 1, figs. 9-10): six to eight chambers in the final whorl, lobate outline, inflated chambers with a boss in the umbilicus.

Morphotype B (Plate 1, figs. 7-8): 7-10 chambers visible in the umbilical side, slightly lobate outline that progressively become lobate at the end of the last whorl; a small knob is often present in the umbilicus.

Morphotype C (Plate 1, figs. 5-6): 7-11 chambers in the last whorl, rounded or very slightly lobate outline, umbilicus without central knob.

Transitional individuals between A. tepida and A. parkinsoniana are the most commonly deformed taxa in the analysed samples. They show several types of morphological abnormalities of the tests, mainly abnormal protuberances (Plate 2, fig. 11), abnormal additional chambers, distorted chamber arrangement or change in coiling direction (Plate 2, figs. 8, 11), twinned tests, and non-developed tests.

Family Elphidiidae Galloway, 1933

Subfamily Elphidiinae Galloway, 1933

Genus Cribroelphidium Cushman and Brönniman, 1948

Cribroelphidium granosum (d'Orbigny, 1846)

Plate 2, figs. 1-2

1826 Nonionina granosa d'Orbigny: p. 128 (nomen nudum).

1846 Nonionina granosa d'Orbigny: p. 110, pl. 5, figs. 19-20.

1987 Elphidium granosum forma granosum (d'Orbigny, 1846); Jorissen, p. 47, pl. 2, fig. 1.

1988 Elphidium granosum forma granosum (d'Orbigny, 1846); Jorissen, p. 104, pl. 2, figs. 12, pl. 16, figs. 1-5.

1993 Elphidium granosum (d'Orbigny, 1846); Sgarrella and Montcharmont-Zei, p. 229, pl. 21, figs. 1-2

2005 Elphidium granosum (d'Orbigny, 1846); Rasmussen, p. 110, pl. 19, fig. 8.

2012 Elphidium granosum (d'Orbigny, 1846); Milker and Schmiedl, p. 121, fig. 27, 17-18.

Description and remarks: Test planispiral, involute, with six to eight chambers in the last whorl. Lobate or slightly lobate outline, convex profile with flattened sides, broadly rounded periphery. The sutures are backward curved, slightly depressed, and open towards the umbilical area. Umbilicus slightly depressed covered by papillae. Primary aperture at the base of the last chamber, formed by a row of small openings. Test coarsely perforated, apertural face imperforate. Pustules are present at the base of the last chamber, near the aperture and in the whole umbilical area, including the inner portion of the sutures.

Distribution: In the Mediterranean, this species is reported from lagoonal to infralittoral environments and it is abundant near the river mouths (Sgarrella and Barra, 1984; Zampi and D'Onofrio, 1986; Sgarrella and Montcharmont Zei, 1993). In the Adriatic Sea, it is common in a narrow belt between 17.5 and $30 \mathrm{~m}$ water depth, on clayey bottoms enriched in organic matter (Jorissen, 1988). It is one of the most common species in the northern Adriatic and in the adjacent Venice Lagoon, from the innermost to the outer lagoonal areas (Albani and Serandrei Barbero, 1990).

Cribroelphidium lidoense (Cushman, 1936)

Plate 2, fig. 3

1936 Elphidium lidoense Cushman: p. 86, pl. 15, fig. 6 .

1976 Elphidium tuberculatum (d'Orbigny); Hansen and Lykke-Andersen, p. 14, pl. 12, figs. 1-4.

1987 Elphidium granosum forma lidoense Cushman; Jorissen, p. 38, pl. 2, fig. 3.

1988 Elphidium granosum forma lidoense Cushman; Jorissen, p. 105, pl. 17, figs. 1-5.

2013 Elphidium granosum forma lidoense Cushman; Melis and Covelli, p. 449, pl. 1, fig. 21.

2016 Elphidium lidoense Cushman; Darling et al., p. 10 , fig. 3, S13.

Description and remarks: Test planispirally enrolled, involute, with 8-12 chambers in the last whorl. Rounded to moderately lobate outline, convex profile with flattened sides, periphery broadly rounded. Backward curved, slightly depressed sutures. Slightly depressed umbilicus occupied by distinct flat-topped knobs, surrounded by pustules. The primary aperture is formed by a series of rounded openings in the interiomarginal position. The test is coarsely perforated, except to the apertural face, which is imperforate. Papillae are present in the umbilical region and at the base of the last chamber.

Cribroelphidium granosum has often been confused with C. lidoense, but they can be distinguished by a series of features (Jorissen, 1988): (i) C. granosum has a lower number of chambers (6-8) than $C$. lidoense (8-12); (ii) the umbilicus of $C$. granosum is occupied only by pustules or, if any, very 
small knobs, whereas several prominent bosses are present in C. lidoense; (iii) sutures that open towards the centre of the test are typical of $C$. granosum, in contrast to thin sutures of $C$. lidoense; and (iv) the test outline of $C$. granosum is usually more lobate than the rounded one of $C$. lidoense. Intermediate morphotypes of these end-members are commonly recorded in the Adriatic Sea (Jorissen, 1988).

Results of recent genetic studies (Darling et al., 2016) performed on benthic foraminifera with a morphology comparable to $C$. lidoense reveal that this is a distinct species and it was classified as Elphidium lidoense. However, genetic sequencing of $C$. granosum was not performed; therefore, a study on this species is needed to understand if it can be regarded as a form or a separated species.

Distribution: This species is reported from infralittoral and circalittoral zones of the Mediterranean (Blanc-Vernet, 1969) and it reaches high concentrations in the shallowest part of the Adriatic Sea (Jorissen, 1988). It also occurs in the outer lagoons, with low frequencies (Melis and Covelli, 2013).

\section{Cribroelphidium oceanense (d'Orbigny in For-} nasini, 1904)

Plate 2, fig. 4

1826 Polystomella oceanensis d'Orbigny: p. 285 (nomen nudum).

1904 Polystomella oceanensis d'Orbigny; Fornasini, p. 13, pl. 3, fig. 10.

1976 Elphidium gunteri Cole; Hansen and LykkeAndersen, p. 12, pl. 8, figs. 10-12, pl. 9, figs. 1-3.

1997 Elphidium gunteri Cole; Hayward et al., p. 80, pl. 11, figs. 13-15.

2000 Cribroelphidium gunteri (Cole); Coccioni, p.78, fig. 3, 5-6.

2009 Cribroelphidium oceanensis (d'Orbigny); Coccioni et al., p. 261, pl. 1, fig. 8.

2013 Elphidium gunteri (Cole); Melis and Covelli, p. 449, pl. 1, fig. 24.

2016 Elphidium oceanense (d'Orbigny) Darling et al., p. 8 , fig. $3, \mathrm{~S} 3$.

Description and remarks: Test planispiral, involute, with 8-11 chambers in the final whorl. Outline slightly lobulate to clearly lobulate, profile inflated, periphery broadly rounded. The sutures are depressed, straight to backward curved. The ponticuli are present, irregular in number, generally broad and slightly raised from the sutures. The umbilicus is depressed and provided by irregular flat-topped knobs. Sutures, umbilical region, and the base of the apertural face are occupied by papillae. The aperture consists of a series of rounded openings arranged in a single row at the base of the apertural face. The wall is densely and coarsely perforated.

Cribroelphidium oceanense and Cribroelphidium gunteri show similar morphological features, but the latter species presents more chambers (about 14) in the last whorl. Specimens recorded in the studied succession always show a low number of chambers in the final whorl, consistent with the attribution to $C$. oceanense.

Our individuals often have a low number of sutural bridges, especially in the first chambers, where they may be only partially developed. This species commonly presents individuals affected by various types of deformation of the test: abnormal protruding chambers (Plate 2, fig. 15), distorted chambers, change in coiling direction, and also complex forms (Plate 2, fig. 14).

Distribution: This species is very common in the Mediterranean lagoons (Debenay et al., 2000). It occurs in the Venice (Coccioni et al., 2009) and Santa Gilla lagoons (Frontalini et al., 2009). It is recorded with relatively high abundances from the Marano and Grado (Melis and Covelli, 2013), Goro (Coccioni, 2000), and Orbetello lagoons (Zampi and D'Onofrio, 1986), reported as Elphidium or Cribroelphidium gunteri. It typically lives at shallow depths, thriving in the organic-rich innermost and intertidal parts of the lagoons and it is also present, with lower concentrations, in the outer lagoons.

It characterizes oligotypic benthic foraminiferal assemblages in areas subject to high freshwater inputs and industrial discharges (Frontalini et al., 2009). It also shows a great tolerance for high concentrations of nutrients and heavy metals (Coccioni, 2000; Melis and Covelli, 2013).

Cribroelphidium poeyanum (d'Orbigny, 1839)

Plate 2, figs. 6-7

1839 Polystomella poeyana d'Orbigny: p. 55, pl. 8 , figs. 25-26.

1930 Elphidium poeyanum (d'Orbigny); Cushman, p. 25, pl. 10, figs. 4-5.

1976 Elphidium kugleri (Cushmand and Brönnimann); Hansen and Lykke-Andersen, p. 12, pl. 9, figs. 4-8.

1976 Elphidium poeyanum (d'Orbigny); Hansen and Lykke-Andersen, p. 13, pl. 9, figs. 9-12, pl. 10, figs. 1-5.

1983 Cribrononion sp.; Sgarrella et al., p. 92, pl. 3, fig. 7.

1987 Elphidium poeyanum forma poeyanum (d'Orbigny); Jorissen, p. 38, pl. 2, fig. 4.

1988 Elphidium poeyanum (d'Orbigny); Jorissen, p. 116, pl. 2, fig. 4a-b, pl. 22, fig. 3a-b, pl. 23, fig. 3 . 
2001 Elphidium poeyanum (d'Orbigny); Fiorini and Vaiani, p. 392, pl. 8, figs. 8-9.

Description and remarks: Test planispiral, involute, with six to eight chambers in the last whorl. Outline slightly lobulate to lobulate, profile slightly inflated, periphery broadly rounded. Sutures slightly depressed, increasingly backward curved in the last whorl. The ponticuli are short. The umbilical region can be depressed and it is covered by a flaplike projection of the last chamber. A row of interiomarginal openings at the base of the apertural face forms the primary aperture. The test is smooth, finely perforated by small pores. Ponticuli, flap projections on the umbilicus and apertural face, are imperforate.

Cribroelphidium poeyanum differs from Cribroelphidium decipiens (Costa, 1856) by the lower number of chambers and the more lobate test, but the latter species is not present in our samples.

Distribution: In the Adriatic Sea, C. poeyanum lives in shallow areas influenced by the fluvial run-off, with relatively high concentrations of organic matter, but it shows only a little tolerance for oxygen deficiency (Jorissen, 1988). This species is also recorded north of the Po Delta and in the Venice Lagoon (Albani and Serandrei Barbero, 1990).

Genus Elphidium de Montfort, 1808

Elphidium advenum (Cushman, 1922)

Plate 1, fig. 21

1922 Polystomella advena Cushman: p. 56, pl. 9, figs. 11, 12.

1930 Elphidium advenum (Cushman); Cushman, p. 25 , pl. 10, figs. 1-2.

1976 Elphidium advenum (Cushman); Hansen and Lykke-Andersen, p. 7, pl. 2, figs. 10-11.

1988 Elphidium advenum (Cushman); Jorissen, p. 22, pl. 2, figs. 9-10.

1990 Cribrononion advenum (Cushman); Albani and Serandrei Barbero, p. 316, pl. 4, fig. 16.

1993 Elphidium advenum (Cushman); Hohenegger et al., p. 81, pl. 1, fig. 9 .

1993 Elphidium punctatum (Terquem); Sgarrella and Montcharmont-Zei, p. 230, pl. 21, figs. 3-4.

2001 Elphidium advenum (Cushman); Fiorini and Vaiani, p. 388, pl. 7, figs. 10, 12-13.

2005 Elphidium advenum (Cushman); Rasmussen, p. 108, pl. 18, figs. 13-15.

2012 Elphidium advenum (Cushman); Milker and Schmiedl, p. 119, fig. 27, 7-8.

2013 Elphidium gerthi van Voorthuysen; Melis and Covelli, p. 449, pl. 1, fig. 22.
Description and remarks: Planispiral, involute test with 10-14 chambers in the final whorl. Circular to very slightly lobulate outline, slightly biconvex profile and acute, keeled periphery. The sutures are slightly depressed and backward curved. Sutural bridges are relatively numerous, raised from the sutures, and flush with the chamber wall. The umbilicus is occupied by a flat, circular boss. Chambers overlap near the umbilical area. Small papillae are present along the sutures, at the base of the apertural face, and within a small collar rim near the last chambers. A series of rounded openings in the apertural face defines the aperture. The wall is smooth.

Distribution: This species is widespread in the Mediterranean, reported especially from the infralittoral and circalittoral zones (Blanc-Vernet, 1969; Milker and Schmiedl, 2012). Elphidium advenum is commonly recorded in the Adriatic Sea and it is considered tolerant to low salinity and pollution (Jorissen, 1988). It is also reported from the Venice, Marano, and Grado lagoons and from the Gulf of Trieste (Albani and Serandrei Barbero, 1990; Hohenegger et al., 1993; Melis and Covelli, 2013). This species has also been found near the inlets of the Fogliano and Lungo coastal lakes, strongly related to sandy bottoms (Carboni et al., 2009).

\section{Elphidium clavatum (Cushman, 1930)}

Plate 1, fig. 22

1930 Elphidium incertum var. clavatum Cushman: p. 20, pl. 7, fig. 10.

1953 Elphidium clavatum Cushman; Loeblich and Tappan, p. 98, pl. 19, figs. 8-10.

1982 Elphidium excavatum (Terquem) forma clavata Cushman; Miller et al., p. 124, pl. 1, figs. 5-6, pl. 3, figs. $3-8$, pl. 4 , figs. $2-6$, pl. 4 , figs. 4-8.

1997 Elphidium excavatum clavatum Cushman; Hayward et al., p. 76, pl. 8, figs. 14-17, pl. 9, figs. 1-5.

2016 Elphidium clavatum Cushman; Darling et al., p. 9 , fig. 3, S2.

Description and remarks: Test planispiral, involute, with 9 to 13 slightly inflated chambers in the last whorl. Rounded to slightly lobulate outline, subacute profile. Slightly depressed, moderately arched sutures that close before reaching the umbilicus, forming a ring-shaped area. The ponticuli are moderately short. The umbilicus presents an elevated knob, surrounded by an umbilical collar. Sutures and umbilical collar can be ornamented by papillae. The aperture is formed by a row of small circular openings at the base of the last chamber. Wall thin and translucent. 
This species was originally considered by Cushman (1930) as a variety of E. incertum, then it was elevated to species rank by Loeblich and Tappan (1953), but some authors continued to consider it as a variety or a subspecies. Recent genetic studies (Pillet et al., 2013; Darling et al., 2016) revealed that the morphotype traditionally assigned to $E$. excavatum clavatum is a distinct species and therefore the taxonomic name Elphidium clavatum should be applied.

Only rare deformed specimens of this taxon have been found in our samples, with distorted chambers (Plate 2, fig. 16).

Distribution: This species is found from Arctic to temperate shallow water environments, from normal to reduced salinity waters (Miller and Lohmann, 1982; Darling et al., 2016). It is also reported from brackish to marginal marine environments of New Zealand, where it dominates benthic foraminiferal assemblages of middle estuaries (Hayward et al., 1997). Direct observations revealed that E. excavatum is a motile species able to shift from infaunal to elevated epifaunal in response to oxygen and nutrient concentrations; therefore, it is considered highly adaptable to changing environmental conditions (Linke and Lutze, 1993).

Elphidium gerthi van Voorthuysen, 1957

Plate 1, fig. 23

1957 Elphidium gerthi van Voorthuysen: p. 32, pl. 23, fig. 12.

1976 Elphidium gerthi van Voorthuysen; Hansen and Lykke-Andersen, p. 10, pl. 5, figs. 7-12.

1991 Elphidium gerthi van Voorthuysen; Cimerman and Langer, p. 78, pl. 91, figs. 1-2.

Description and remarks: Test planispiral, involute, with 10-12 chambers in the final whorl. Outline from moderately rounded to slightly lobulate, test profile compressed and acutely rounded periphery. Depressed, backward curved sutures. Sutural bridges are variable in number, slightly raised from the sutures. The umbilicus is depressed and provided with a prominent knob. Chambers are fused near the umbilical area, forming an almost complete ring-shaped area around the umbilicus, which is interrupted by longer, distinct sutures of the last chambers. Pustules cover the sutures and the depressed umbilical area around the knob. A row of openings at the base of the last chamber form the aperture. The wall has a smooth surface.

In our individuals, ponticuli are less evident in the last chambers, where they are often covered by pustules.

Only one specimen with an aberrant chamber shape has been found in our samples.

Distribution: Elphidium gerthi is reported from shallow, strong fluvially influenced waters of the Baltic Sea, the British Channel, and the Gulf of Cádiz, usually related to sandy or vegetated bottoms (Murray, 2006; Mendes et al., 2012). Hansen and Lykke-Andersen (1976) report the presence of this species from the shallow Kattegat Sea.

\section{Elphidium sp. 1}

Plate 1, figs. 24-25

Test planispirally enrolled, involute, with 7-10 chambers in the last whorl. Outline perfectly rounded to slightly lobulate, profile compressed with acutely rounded and carinate periphery. Backward curved and depressed sutures, usually quite deep especially among the last chambers. Sutural bridges are evident, thick, and broad. Umbilicus slightly depressed or flush with the chambers, without knobs. The primary aperture is formed by a series of openings at the base of the apertural face. Abundant, evident pustules and pseudospines cover sutures, ponticuli, border of chambers, umbilical area, and the base of the apertural face. The central part of the chambers is ornamented with slightly or well-developed pustules, but it can be also smooth, especially in the last chambers.

This species differs from Elphidium margaritaceum (Cushman, 1930) by the more compressed profile, the lower number of ponticuli and the coverage of pustules, which is not complete in our individuals.

Only rare aberrant individuals attributed to this taxon, mainly with a distorted chamber arrangement, are present in our assemblages.

\section{Elphidium sp. 2}

Plate 1, figs. 26-27

Test planispiral, involute, with approximately 9-10 chambers in the last whorl. Rounded outline, profile biconvex with flat sides, slightly rounded to acutely rounded periphery. Sutures backward curved, slightly or almost not depressed. A few, short ponticuli that tend to disappear in the last chambers. The umbilicus is slightly depressed. Small openings in the interiomarginal position at the base of the apertural face form the primary aperture, which is partially covered by pustules or pseudo-spines. Papillae are also present on the sutures and on the umbilical area. The wall is generally smooth, except for the area covered by pustules.

Subfamily Notorotaliinae Hornibrook, 1961

Genus Parrellina Thalmann, 1951

Parrellina verriculata (Brady, 1881)

Plate 2, fig. 5

1881 Polystomella verriculata Brady: p. 66.

1991 Elphidium sp. 5; Cimerman and Langer, p. 80 , pl. 91 , figs. $8-10$.

1993 Parrellina verriculata (Brady); Sgarrella and Montcharmont Zei, p. 232, pl. 21, fig. 7. 
2012 Parrellina verriculata (Brady); Milker and Schmiedl, p. 122, fig. 27, 27-28.

Description and remarks: Test planispiral, involute, with eight to nine chambers in the final whorl. Rounded to slightly lobulated outline, acute and carinate periphery. Sutures backward curved, occupied by large ponticuli that form subrectangular fossettes. Septal ridges and ponticuli are raised, thick, and form a network on the test. The apertural face is occupied by pustules. The aperture consists of a row of interiomarginal rounded openings. Sutures and umbilicus are ornamented with pustules.
Distribution: This species is recorded in the Mediterranean Sea and reported from Posidonia prairies and the upper circalittoral zone (Blanc-Vernet, 1969; Sgarrella and Montcharmont Zei, 1993). 


\section{The Supplement related to this article is available online at https://doi.org/10.5194/jm-37-203-2018-supplement.}

Author contributions. Both authors defined the design of the work and carried out benthic foraminiferal analyses, whereas the ostracod analyses and statistical elaborations were performed by GB. Interpretation of fossil data and preparation of the paper was contributed to by both authors.

Competing interests. The authors declare that they have no conflict of interest.

Acknowledgements. We are grateful to Regione EmiliaRomagna - RER - Geological, Seismic and Soil Survey for providing core material. Thanks are due to Maria Roberta Randi for the SEM assistance. We warmly thank the editor Thomas M. Cronin, Virgilio Frezza, and the anonymous reviewer for their constructive comments that greatly improved the quality of the work.

Edited by: Thomas M. Cronin

Reviewed by: Virgilio Frezza and one anonymous referee

\section{References}

Aiello, G., Barra, D., Coppa, M. G., Valente, A., and Zeni, F: Recent infralittoral Foraminiferida and Ostracoda from the Porto Cesareo Lagoon (Ionian Sea, Mediterranean), B. Soc. Paleontol. Ital., 45, 1-14, 2006.

Aladin, N. V.: Salinity tolerance, morphology and physiology of the osmoregulation organs in Ostracoda with special reference to Ostracoda from the Aral Sea, in: Ostracoda in the Earth and Life Sciences, edited by: Jones, P. and McKenzie, K., A. A. Balkema, Rotterdam, 387-403, 1993.

Albani, A. and Serandrei Barbero, R.: I Foraminiferi della Laguna e del Golfo di Venezia, Memorie di Scienze Geologiche, 42, 271341, 1990.

Almogi-Labin, A., Perelis-Grossovicz, L., and Raab, M.: Living Ammonia from a hypersaline inland pool, Dead Sea area, Israel, J. Foramin. Res., 22, 257-266, 1992.

Alve, E.: Benthic foraminifera in sediment cores reflecting heavy metal pollution in Sørfjord, Western Norway, J. Foramin. Res., 21, 1-19, 1991.

Alve, E.: Benthic foraminiferal responses to estuarine pollution: a review, J. Foramin. Res., 25, 190-203, 1995

Alve, E. and Murray, J. W.: Ecology and taphonomy of benthic foraminifera in a temperate mesotidal inlet, J. Foramin. Res., 24, 18-27, 1994.

Alve, E. and Murray, J. W.: Marginal marine environments of the Skagerrak and Kattegat: a baseline study of living (stained) benthic foraminiferal ecology, Palaeogeogr. Palaeocl., 146, 171193, 1999.

Alves Martins, M. V., Helali, M. A., Zaaboub, N., BoukefBenOmrane, I., Frontalini, F., Reis, D., Portela, H., Martins
Matos Moreira Clemente, I., Nogueira, L., Pereira, E., Miranda, P., El Bour, M., and Aleya, L.: Organic matter quantity and quality, metals availability and foraminiferal assemblages as environmental proxy applied to the Bizerte Lagoon (Tunisia), Mar. Pollut. Bull., 105, 161-179, 2016.

Amorosi, A. and Colalongo, M. L.: The linkage between alluvial and coeval nearshore marine successions: evidence from the Late Quaternary record of the Po River Plain, Italy, in: Fluvial Sedimentology VII, edited by: Blum, M. D., Marriott, S. B., and Leclair, S. F., Blackwell Publishing Ltd., Oxford, 257-275, 2005.

Amorosi, A., Colalongo, M. L., Fusco, F., Pasini, G., and Fiorini, F.: Glacio-eustatic control of continental-shallow marine cyclicity from Late Quaternary deposits of the southeastern Po Plain (Northern Italy), Quaternary Res., 52, 1-13, 1999a.

Amorosi, A., Colalongo, M. L., Pasini, G., and Preti, D.: Sedimentary response to Late Quaternary sea-level changes in the Romagna coastal plain (northern Italy), Sedimentology, 46, 99-121, 1999b.

Amorosi, A., Colalongo, M. L., Fiorini, F., Fusco, F., Pasini, G., Vaiani, S. C., and Sarti, G.: Palaeogeographic and palaeoclimatic evolution of the Po Plain from 150-ky core records, Global Planet. Change, 40, 55-78, 2004.

Amorosi, A., Rossi, V., Scarponi, D., Vaiani, S. C., and Ghosh, A.: Biosedimentary record of postglacial coastal dynamics: highresolution sequence stratigraphy from the northern Tuscan coast (Italy), Boreas, 43, 939-954, 2014.

Arbulla, D., Pugliese, N., and Russo, A.: Ostracods from the National Park of La Maddalena Archipelago (Sardinia, Italy), B. Soc. Paleontol. Ital., 43, 91-99, 2004.

Armynot du Châtelet, E. and Debenay, J. P.: Anthropogenic impact on the western French coast as revealed by foraminifera: a review, Revue de Micropaléontologie, 53, 129-137, 2010.

Athersuch, J., Horne, D. J., and Whittaker, J. E.: Marine and brackish water ostracods, in: Synopses of the British Fauna (New Series), 43, edited by: Kermack, D. M. and Barnes, R. S. K., Brill E.J., Leiden, 345 pp., 1989.

Banner, F. T. and Culver, S. J.: Quaternary Haynesina n. gen. and Paleogene Protelphidium Haynes; their morphology, affinities and distribution, J. Foramin. Res., 8, 177-207, 1978.

Bik, A.: An aberrant Nonionid from the Miocene of the Mayence basin, Notizblatt des Hessischen Landesamtes für Bodenforschung zu Wiesbaden, 92, 68-74, 1964.

Blanc-Vernet, L.: Contribution à l'étude des foraminifères de Méditerranée, Travaux de la Station Marine d'Endoume, Marseille, France, 1969.

Boltovskoy, E., Scott, D. B., and Medioli, F. S.: Morphological variations of benthic foraminiferal tests in response to changes in ecological parameters: a review, J. Paleontol., 65, 175-185, 1991.

Bonaduce, G., Ciampo, G., and Masoli, M.: Distribution of Ostracoda in the Adriatic Sea, Pubblicazioni della Stazione Zoologica di Napoli, 40, 304 pp., 1975.

Bondesan, M., Cibin, U., Colalongo, M. L., Pugliese, N., Stefani, M., Tsakiridis, E., Vaiani, S. C., and Vincenzi, S.: Benthic communities and sedimentary facies recording late Quaternary environmental fluctuations in a Po Delta subsurface succession (Northern Italy), in: Proceedings of the Second and Third Italian Meeting of Environmental Micropaleontology, edited by: Coccioni, R., Lirer, F., and Marsili, A., The Grzybowski Foundation Special Publication, 11, 21-31, 2006. 
Boomer, I., Horne, D. J., and Slipper, J.: The use of ostracods in palaeoenvironmental studies, or what can you do with an ostracod shell?, in: Bridging the gap: Trends in the Ostracode Biological and Geological Sciences, edited by: Park, L. E. and Smith, A. J., The Paleontological Society Papers, 9, 153-179, 2003.

Brady, H. B.: Notes on some reticularian Rhizopoda of the "Challenger” expedition, Part 3, Q. J. Microsc. Sci., 21 , 31-71, 1881.

Breman, E.: The distribution of Ostracodes in the bottom sediments of the Adriatic Sea, PhD thesis, Free University of Amsterdam, the Netherlands, 1975.

Brünnich, M. T.: Zoologiæ fundamenta Prælectionibus Academicis Accommodata - Grunde i dyrlæren, Hafniæ et Lipsiæ, 253 pp., 1772.

Bugrova, E. M.: Morfologicheskij oblik rakovin foraminifer kak pokasatel' uslovij ihk obitanij (The morphology of foraminiferal tests as indicator of their environment), in: Obraz zhisni i zakonomernosti rasselenija sovremennoj i iskopaemoj mikrofauny (Mode of Life and Mechanisms of Settling of Recent and Fossil Microfauna), edited by: Furssenko, A. V., Trudy Instituta Geologii i Geofiziki, Akademija Nauk SSSR, Sibirskoe otdelenie, 333, 439 pp., 1975.

Campo, B., Amorosi, A., and Vaiani, S. C.: Sequence stratigraphy and late Quaternary paleoenvironmental evolution of the Northern Adriatic coastal plain (Italy), Palaeogeogr. Palaeocl., 466, 265-278, 2017.

Carboni, M. G., Succi, M. C., Bergamin, L., Di Bella, L., Frezza, V., and Landini, B.: Benthic foraminifera from two coastal lakes of southern Latium (Italy). Preliminary evaluation of environmental quality, Mar. Pollut. Bull., 59, 268-280, 2009.

Castellarin, A. and Vai, G. B.: South alpine versus Po Plain apenninic arcs, in: The Origin of Arcs, Development in Geotectonics, 20, edited by: Wezel, F. C., Elsevier, Amsterdam, 253-280, 1986.

Cearreta, A., Cachão, M., Cabral, M. C., Bao, R., and Ramalho, M. J.: Lateglacial and Holocene environmental changes in Portuguese coastal lagoons: 2. Reconstruction of the Santo André coastal area (SW Portugal) during the last 14,000 years based on microfossil multiproxy evidence, Holocene, 13, 449-460, 2003.

Cimerman, F. and Langer, M. R.: Mediterranean Foraminifera, Academia Scientiarum et Artium Slovenica, Classis IV, 30, Ljubljana, 118 pp., 1991.

Clarke, K. R.: Non-parametric multivariate analyses of changes in community structure, Aust. J. Ecol., 18, 117-143, 1993.

Coccioni, R.: Benthic foraminifera as bioindicators of heavy metal pollution - a case study from the Goro Lagoon (Italy), in: Environmental micropaleontology: the application of microfossils to environmental geology, edited by: Martin, R. E., Kluwer Academic/Plenum Publishers, New York, 71-103, 2000.

Coccioni, R., Frontalini, F., Marsili, A., and Mana, D.: Benthic foraminifera and trace element distribution: A case-study from the heavily polluted lagoon of Venice (Italy), Mar. Pollut. Bull., 59, 257-267, 2009.

Colalongo, M. L.: Ricerche sugli Ostracodi nei fondali antistanti il delta del Po, Giornale di Geologia, 36, 335-362, 1969.

Costa, O. G.: Paleontologia del regno di Napoli contenente la descrizione e figura di tutti gli avanzi organici fossili racchuisi nel suolo di questo regno, Napoli, 512 pp., 1856.

Cushman, J. A.: Results of the Hudson Bay Expedition, 1920 - 1, The foraminifera, Contributions to Canadian Biology, for 1921, 135-147, 1922.
Cushman, J. A.: Recent Foraminifera from Porto Rico, Publications of the Carnegie Institution of Washington, 344 pp., 1926.

Cushman, J. A.: The foraminifera of the Atlantic Ocean, Part 7: Nonionidae, Camerinidae, Peneroplidae and Alveolinellidae, Bulletin of the United States National Museum, 104, 1-79, 1930.

Cushman, J. A.: Some new species of Elphidium and related genera, Contributions from the Cushman Laboratory for Foraminiferal Research, 12, 78-91, 1936.

Cushman, J. A. and Brönnimann, P.: Some new genera and species of foraminifera from brackish water of Trinidad, Contributions from the Cushman Laboratory for Foraminiferal Research, 24, 15-21, 1948.

Darling, K. F., Schweizer, M., Knudsen, K. L., Evans, K. M., Bird, C., Roberts, A., Filipsson, H. L., Kim, J. H., Gudmundsson, G., Wade, C. M., Sayer, M. D. J., and Austin, W. E. N.: The genetic diversity, phylogeography and morphology of Elphidiidae (Foraminifera) in the Northeast Atlantic, Mar. Micropaleontol., 129, 1-23, 2016.

Debenay, J. P., Guillou, J. J., Redois, F., and Geslin, E.: Distribution trends of foraminiferal assemblages in paralic environments: a base for using foraminifera as bioindicators, in: Environmental micropaleontology: the application of microfossils to environmental geology, edited by: Martin, R. E., Kluwer Academic/Plenum Publishers, New York, 39-67, 2000.

de Montfort, D.: Conchyliologie Systematique et Classification Methodique des Coquilles, F. Schoell, Paris, 1808.

de Nooijer, L. J., Duijnstee, I. A. P., and van der Zwaan, G. J.: Spatial distribution of intertidal benthic foraminifera in the Dutch Wadden Sea, Geologica Ultraiectina, 272, 21-32, 2007.

Dinelli, E., Ghosh, A., Rossi, V., and Vaiani, S. C.: Multiproxy reconstruction of Late Pleistocene-Holocene environmental changes in coastal successions: microfossil and geochemical evidences from the Po Plain (Northern Italy), Stratigraphy, 9, 153-167, 2013.

Donnici, S. and Serandrei Barbero, R.: The benthic foraminiferal communities of the northern Adriatic continental shelf, Mar. Micropaleontol., 44, 93-123, 2002.

D'Onofrio, S., Marabini, F., and Vivalda, P.: Foraminiferi di alcune lagune del delta del Po, Giornale di Geologia, 40, 267-276, 1976

d'Orbigny, A.: Tableau Methodique de la Classe des Cephalopodes, Ann. Sci. Nat. Zool., 7, 96-314, 1826.

d'Orbigny, A.: Foraminiféres, in: Histoire physique, politique et naturelle de L'ile de Cuba, edited by: De la Sagra, R. M., Bertrand A., Paris, 1839.

d'Orbigny, A.: Foraminiféres fossils du bassin tertiarie de Vienne (Autriche) (Die fossilen Foraminiferen des tertiaeren Beckens von Wien), Gide et Comp., Paris, 110 pp., 1846.

Dutton, A., Bard, E., Antonioli, F., Esat, T. M., Lambeck, K., and McCulloch, M. T.: Phasing and amplitude of sea-level and climate change during the penultimate interglacial, Nat. Geosci., 2, 355-359, 2009.

Ehrenberg, C. G.: Über die Bildung der Kreidefelsen und des Kreidemergels durch unsichtbare Organismen, Abhandlungen der Königlichen Akademie der Wissenschaften in Berlin 1838, 60$148,1839$.

Ehrenberg, C. G.: Eine weitere Erläuterung des Organismus mehrerer in Berlin lebend beobachteter Polythalamien der Nordsee, K. Preuss. Akad. Wiss., Berlin, 18-23, 1840. 
Ellis, B. F. and Messina, A. R.: Catalogue of Foraminifera, Micropaleontology Press, New York, 1940.

Engel, M., Brückner, H., Pint, A., Wellbrock, K., Ginau, A., Voss, P., Grottker, M., Klasen, N., and Frenzel, P.: The early Holocene humid period in NW Saudi Arabia - evidence from sediments, microfossils and palaeo-hydrological modelling, Quaternary Int., 266, 131-141, 2012.

Field, J. G., Clarke, K. R., and Warwick, R. M.: A practical strategy for analyzing multispecies distribution patterns, Mar. Ecol.-Prog. Ser., 8, 37-52, 1982.

Fiorini, F.: Benthic foraminiferal associations from Upper Quaternary deposits of southeastern Po Plain, Italy, Micropaleontology, 50, 45-58, 2004.

Fiorini, F. and Vaiani, S. C.: Benthic foraminifers and transgressiveregressive cycles in the Late Quaternary subsurface sediments of the Po Plain near Ravenna (Northern Italy), B. Soc. Paleontol. Ital., 40, 357-403, 2001.

Fornasini, C.: Illustrazione di specie orbignyane di foraminiferi istituite nel 1826, Memorie della Reale Accademia delle Scienze dell'Istituto di Bologna, series 6(I), 1904

Frenzel, P., Keyser, D., and Viehberg, F. A.: An illustrated key and (palaeo)ecological primer for recent to postglacial Ostracoda (Crustacea) of the Baltic Sea, Boreas, 39, 567-575, 2010.

Frenzel, P., Schulze, I., and Pint, A.: Noding of Cyprideis torosa valves (Ostracoda) - a proxy for salinity? New data from field observations and a long-term microcosm experiment, Int. Rev. Hydrobiol., 97, 314-329, 2012.

Frontalini, F. and Coccioni, R.: Benthic foraminifera for heavy metal pollution monitoring: a case study from the central Adriatic Sea coast of Italy, Estuar. Coast. Shelf S., 76, 404-417, 2008.

Frontalini, F. and Coccioni, R.: Benthic foraminifera as bioindicators of pollution: a review of Italian research over the last three decades, Revue de Micropaléontologie, 54, 115-127, 2011.

Frontalini, F., Buosi C., Da Pelo, S., Coccioni, R., Cherchi, A., and Bucci C.: Benthic foraminifera as bio-indicators of trace element pollution in the heavily contaminated Santa Gilla lagoon (Cagliari, Italy), Mar. Pollut. Bull., 58, 858-877, 2009.

Frontalini, F., Margaritelli, G., Francescangeli, F., Rettori, R., Armynot du Châtelet, E., and Coccioni, R.: Benthic Foraminiferal Assemblages and Biotopes in a Coastal Lake: The Case Study of Lake Varano (Southern Italy), Acta Protozool., 52, 147-160, 2013.

Galloway, J. J.: A Manual of Foraminifera, Principia Press, Bloomington, 483 pp., 1933.

Geslin, E., Debenay, J. P., and Lesourd, M.: Abnormal wall textures and test deformation in Ammonia beccarii (hyaline foraminifer), J. Foramin. Res., 28, 148-156, 1998.

Geslin, E., Debenay, J. P., Duleba, W., and Bonetti, C.: Morphological abnormalities of foraminiferal tests in Brazialian environments: comparison between polluted and non-polluted areas, Mar. Micropaleontol., 45, 151-168, 2002.

Gliozzi, E. and Mazzini, I.: Palaeoenvironmental analysis of Early Pleistocene brackish marshes in the Rieti and Tiberino intrapenninic basins (Latium and Umbria, Italy) using ostracods (Crustacea), Palaeogeogr. Palaeocl., 140, 325-333, 1998.

Goldstein, S. T. and Corliss, B. H.: Deposit feeding in selected deepsea and shallow-water benthic foraminifera, Deep-Sea Res. Pt. I, 41, 229-241, 1994.
Guelorget, O. and Perthuisot, J. P.: Le domaine paralique: expressions géologiques, biologiques et économiques du confinement, Travaux du laboratoire de Géologie, 16, Paris, 136 pp., 1983.

Hammer, Ø., Harper, D. A. T., and Ryan, P. D.: PAST: Paleontological Statistics Software Package for Education and Data Analysis, Palaeontol. Electron., 4, 1-9, 2001.

Hansen, H. J. and Lykke-Andersen, A.-L.: Wall structure and classification of fossil and recent elphidiid and nonionid Foraminifera, Fossils and Strata, 10, 1-37, 1976.

Hayward, B. W., Hollis, C. J., and Grenfell, H. R.: Recent Elphidiidae (Foraminiferida) of the South-west Pacific and fossil Elphidiidae of New Zealand, Institute of Geological \& Nuclear Sciences monograph, 16, Lower Hutt, New Zealand, 170 pp., 1997.

Henderson, P. A.: Freshwater ostracods, in: Synopses of the British Fauna (New Series), 42, edited by: Kermack, D. M. and Barnes, R. S. K., Brill E.J., Leiden, 228 pp., 1990.

Heron-Allen, A. and Earland, A.: Clare Island Survey; Part 64 The foraminifera of the Clare Island District, Co. Mayo, Ireland, P. Roy. Irish Acad., 31, 1-188, 1913.

Hohenegger, J., Piller, W. E., and Baal, C.: Horizontal and vertical spatial microdistribution of foraminifers in the shallow subtidal Gulf of Trieste, Northern Adriatic Sea, J. Foramin. Res., 23, 79 101, 1993.

Holzmann, M. and Pawlowski, J.: Taxonomic relationships in the genus Ammonia (Foraminifera) based on ribosomal DNA sequences, J. Micropalaeontol., 19, 85-95, 2000.

Hornibrook, de B. N.: Tertiary Foraminifera from Oamaru District (N.Z). Part 1-Systematics and Distibution, New Zealand Geological Survey Paleontological Bulletin, 34, 1-194, 1961.

Jorissen, F. J.: The distribution of benthic foraminifera in the Adriatic Sea, Mar. Micropaleontol., 12, 21-48, 1987.

Jorissen, F. J.: Benthic Foraminifera from the Adriatic Sea; principles of phenotypic variation, Utrecht Micropaleontological Bulletins, 37, 176 pp., 1988.

Keyser, D. and Aladin, N.: Noding in Cyprideis torosa and its causes, Studia Quaternaria, 2, 19-24, 2004.

Laut, L. L. M., Clemente, I. M. M. M., Belart, P., Martins, M. V. A., Frontalini, F., Laut, V. M., Gomes, A., Boski, T., Lorini, M. L., Fortes, R. R., and Rodrigues, M. A. C.: Multiproxies (benthic foraminifera, ostracods and biopolymers) approach applied to identify the environmental partitioning of the Guadiana River Estuary (Iberian Peninsula), Journal of Sedimentary Environments, 1, 184-201, 2016.

Le Cadre, V. and Debenay, J. P.: Morphological and cytological responses of Ammonia (foraminifera) to copper contamination: implication for the use of foraminifera as bioindicators of pollution, Environ. Pollut., 143, 304-317, 2006.

Legendre, P. and Legendre, L.: Numerical Ecology, 3rd Edn., Elsevier B.V., Amsterdam, the Netherlands, 2012.

Linke, P. and Lutze, G. F.: Microhabitat preferences of benthic foraminifera a static concept or a dynamic adaptation to optimize food acquisition?, Mar. Micropaleontol., 20, 215-234, 1993.

Lisiecki, L. E. and Raymo, M. E.: A Pliocene-Pleistocene stack of 57 globally distributed benthic $\delta^{18} \mathrm{O}$ records, Paleoceanography, 20, PA1003, https://doi.org/10.1029/2004PA001071, 2005.

Loeblich, A. R. and Tappan, H.: Studies of Arctic foraminifera, Smithsonian Miscellaneous Collections, 12, 150 pp., 1953.

Loeblich, A. R. and Tappan, H.: Foraminiferal Genera and Their Classification, Van Nostrand Reinhold, New York, 970 pp., 1987. 
Marco-Barba, J.: Freshwater ostracods ecology and geochemistry as paleoenvironmental indicators in marginal marine ecosystems: a case of study, the Albufera of Valencia, $\mathrm{PhD}$ thesis, Universidad de Valencia, 2010.

Marco-Barba, J., Holmes, J. A., Mesquita-Joanes, F., and Miracle, M. R.: The influence of climate and sea-level change on the Holocene evolution of a Mediterranean coastal lagoon: Evidence from ostracod palaeoecology and geochemistry, Geobios, 46, 409-421, 2013.

Margerel, J. P.: Aubignyna, noveau genre de foraminifères du Pliocène du Bosq d'Aubigny (Manche), Revue de Micropaléontologie, 13, 58-64, 1970.

Martínez-García, B., Pascual, A., Rodríguez-Lázaro, J., MartínRubio, M., and Rofes, J.: The Ostracoda (Crustacea) of the Tina Menor estuary (Cantabria, southern Bay of Biscay): Distribution and ecology, J. Sea Res., 83, 111-122, 2013.

Mazzini, I., Anadón, P., Barbieri, M., Castorina, F., Ferreli, L., Gliozzi, E., Mola, M., and Vittori, E.: Late Quaternary sealevel changes along the Tyrrhenian coast near Orbetello (Tuscany, Central Italy): paleoenvironmental reconstruction using ostracods, Mar. Micropaleontol., 37, 289-311, 1999.

Meisch, C.: Freshwater Ostracoda of Western and Central Europe, in: Süsswasserfauna von Mitteleuropa 8/3, Schwoerbel, J. and Zwick, P., Spektrum Akademischer Verlag, Heidelberg, Berlin, 522 pp., 2000.

Melis, R. and Covelli, S.: Distribution and morphological abnormalities of recent foraminifera in the Marano and Grado Lagoon (North Adriatic Sea, Italy), Mediterr. Mar. Sci., 14, 432-450, 2013.

Mendes, I., Dias, J. A., Schönfeld, J., and Ferreira, O.: Distribution of living benthic foraminifera on the northern Gulf of Cadiz continental shelf, J. Foramin. Res., 42, 18-38, 2012.

Milker, Y. and Schmiedl, G.: A taxonomic guide to modern benthic shelf foraminifera of the western Mediterranean Sea, Palaeontol. Electron., 15, 134 pp., 2012.

Miller, K. and Lohmann, G.: Environmental distribution of Recent benthic foraminifera on the northeast United States continental slope, Geol. Soc. Am. Bull., 93, 6-200, 1982.

Montenegro, M. E. and Pugliese, N.: Autecological remarks on the ostracod distribution in the Marano and Grado Lagoons (Northern Adriatic Sea Italy), B. Soc. Paleontol. Ital., 3, 123-132, 1996.

Murray, J. W.: Ecology and applications of benthic foraminifera, Cambridge University Press, Cambridge, 426 pp., 2006.

Murray, J. W., Whittaker, J. E., and Alve, E.: On the type species of Aubignyna and a description of A. hamblensis, a new microforaminifer from temperate shallow waters, J. Micropalaeontol., 19, 61-67, 2000.

Pielou, E. C.: Ecological Diversity, John Wiley, New York, 165 pp., 1975.

Pieri, M. and Groppi, G.: Subsurface geological structure of the Po Plain, Italy, Pubblicazione del Progetto Finalizzato Geodinamica, 414, 1-23, 1981.

Pieri, V., Martens, K., Meisch, C., and Rossetti, G.: An annotated checklist of the Recent non-marine ostracods (Ostracoda: Crustacea) from Italy, Zootaxa, 3919, 271-305, 2005.

Pillet, L., Voltski, I., Korsun, S., and Pawlowski, J.: Molecular phylogeny of Elphidiidae (foraminifera), Mar. Micropaleontol., 103, $1-14,2013$.
Pint, A. and Frenzel, P.: Ostracod fauna associated with Cyprideis torosa - an overview, J. Micropalaeontol., 36, 113-119, 2017.

Pint, A., Frenzel, P., Fuhrmann, R., Scharf, B., and Wennrich, V.: Distribution of Cyprideis torosa (Ostracoda) in: Quaternary athalassic sediments in Germany and its application for palaeoecological reconstructions, Int. Rev. Hydrobiol., 97, 330-355, 2012.

Pint, A., Engel, M., Melzer, S., Frenzel, P., Plessen, B., and Brückner, H.: How to discriminate athalassic and marginal marine microfaunas: foraminifera and other fossils from an early Holocene continental lake in northern Saudi Arabia, J. Foramin. Res., 47, 175-187, 2017.

Rasmussen, T. L.: Systematic paleontology and ecology of benthic foraminifera from the Plio-Pleistocene Kallithea Bay Section, Rhodes, Greece, in: Lagoon to deepwater foraminifera and ostracods from the Plio-Pleistocene Kallithea bay section, Rhodes, Greece, edited by: Thomsen, E., Cushman Foundation Special Publication, 39, 53-157, 2005.

Regione Emilia-Romagna and ENI-AGIP: Riserve idriche sotterranee della Regione Emilia-Romagna, S.EL.CA, Firenze, 1998.

Rodriguez-Lazaro, J. and Ruiz-Muñoz, F.: A General Introduction to ostracods: morphology, distribution, fossil record and applications, in: Ostracoda as proxies for Quaternary climate change, edited by: Horne, D. J., Holmes, J. A., Rodriguez-Lazaro, J., and Viehberg, F., Developments in Quaternary Science, 17, Elsevier, 1-14, 2012.

Rossi, V., Amorosi, A., Sarti, G., and Potenza, M.: Influence of inherited topography on the Holocene sedimentary evolution of coastal systems: An example from Arno coastal plain (Tuscany, Italy), Geomorphology, 135, 117-128, 2011.

Ruiz, F., González-Regalado, M. L., Baceta, J. I., MenegazzoVitturi, L., Pistolato, M., Rampazzo, G., and Molinaroli, E.: Los ostrácodos actuales de la laguna de Venecia (NE de Italia), Geobios, 33, 447-454, 2000.

Saidova, K. M.: On an up-to-date system of supraspecific taxonomy of Cenozoic benthonic foraminifera, Institut Okeanologii P.P.Shirshova, Akademiya Nauk, SSSR, Moscow, 73 pp., 1981 (in Russian).

Salel, T., Bruneton, H., and Lefèvre, D.: Ostracods and environmental variability in lagoons and deltas along the north-western Mediterranean coast (Gulf of Lions, France and Ebro delta, Spain), Revue de Micropaléontologie, 59, 425-444, 2016.

Scott, D. B. and Medioli, F. S.: Quantitative studies of marsh foraminiferal distributions in Nova Scotia: implications for sea level studies, Cushman Foundation for Foraminiferal Research Special Publication, 17, 1-58, 1980.

Schultze, M. S.: Über den Organismus der Polythalamien (Foraminiferen) nebst Bemerkungen über die Rhizopoden im Allgemeinen, Engelmann, Leipzig, 1854.

Sgarrella, F. and Barra, D.: Distribuzione dei foraminiferi bentonici nel Golfo di Salerno (Basso Tirreno, Italia), Bollettino della società dei naturalisti di Napoli, 93, 51-110, 1984.

Sgarrella, F. and Moncharmont Zei, M.: Benthic Foraminifera of the Gulf of Naples (Italy): systematics and autoecology, B. Soc. Paleontol. Ital., 32, 145-264, 1993.

Sgarrella, F., Barra, D., and Improta, A.: The benthic foraminifers of the Gulf of Policastro (Southern Tyrrhenian Sea, Italy), Bollettino della società dei naturalisti di Napoli, 92, 77-114, 1983.

Shannon, C. E.: A mathematical theory of communication, Bell Syst. Tech. J., 27, 379-423, 1948. 
Shupack, B.: Some Foraminifera from western Long Island and New York Harbor, Am. Mus. Novit., 737, 1-12, 1934.

Slack, J. M., Kaesler, R. L., and Kontrovitz, M.: Trend, signal and noise in the ecology of Ostracoda: information from rare species in low-diversity assemblages, Hydrobiologia, 419, 181$189,2000$.

Stouff, V., Geslin, E. G., Debenay, J. P., and Lesourd, M.: Origin of morphological abnormalities in Ammonia (foraminifera): studies in laboratory and natural environments, J. Foramin. Res., 29, 152-170, 1999.

Thalmann, H. E.: Mitteilungen über Foraminiferen, Eclogae Geol. Helv., 43, 221-225, 1951.

Trog, C., Höfer, D., Frenzel, P., Camacho, S., Schneider, H., and Mäusbacher, R.: A multi-proxy reconstruction and comparison of Holocene palaeoenvironmental changes in the Alvor and Alcantarilha estuaries (southern Portugal), Revue de Micropaléontologie, 56, 131-158, 2013.

Uffenorde, H.: Okologie und jahreszeitliche Verteilung rezenter benthonischer Ostracoden des Limski kanal bei Rovinj (nördliche Adria) [Ecology and seasonal distribution of Recent benthonic Ostracodes from the Limski kanal near Rovinj (northern Adriatic Sea)], Göttinger Arbeiten zur Geologie und Paläontologie, 13, Göttingen, 136 pp., 1972.

Vaiani, S. C. and Pennisi, M.: Tracing freshwater provenance in palaeo-lagoons by boron isotopes and relationship with benthic foraminiferal assemblages. A comparison from late Quaternary subsurface successions in Northern and Central Italy, B. Soc. Paleontol. Ital., 53, 55-66, 2014. van Harten, D.: Variable noding in Cyprideis torosa (Ostracoda, Crustacea): an overview, experimental results and a model from Catastrophe Theory, Hydrobiologia, 419, 131-139, 2000.

van Voorthuysen, J. H.: Foraminiferen aus dem Eemien (RissWürm-Interglazial) in der Bohrung Amersfoort I (Locus typicus), Geologische Stichting, Meded., 11, Haarlem, the Netherlands, 1957.

Walker, G. and Jacob, E.: Essays on the Microscope, 2nd Edn., edited by: Adams, G., Dillon and Keating, London, 712 pp., 1798.

Wang, P., Min, Q., and Bian, Y.: On marine continental transitional faunas in Cenozoic deposits of East China, in: Marine Micropaleontology of China, edited by: Wang, P., China Ocean Press, Springer-Verlag, Berlin, New York, 15-33, 1985.

Yanko, V., Kronfeld, J., and Flexer, A.: Response of benthic foraminifera to various pollution sources: implications for pollution monitoring, J. Foramin. Res., 24, 1-17, 1994.

Zampi, M. and D'Onofrio, S.: I foraminiferi della Laguna di Levante (Orbetello, Grosseto), Atti della Società Toscana di Scienze Naturali, Memorie Serie A, 93, 101-127, 1986. 